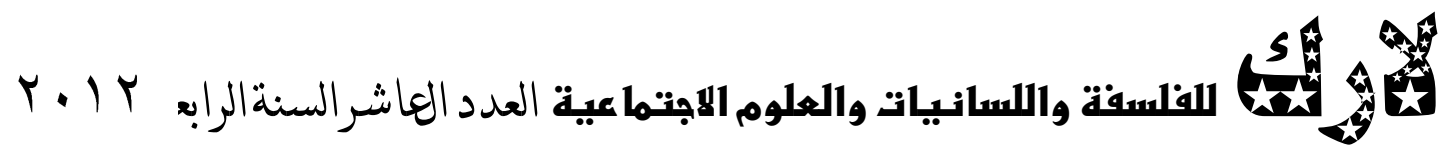

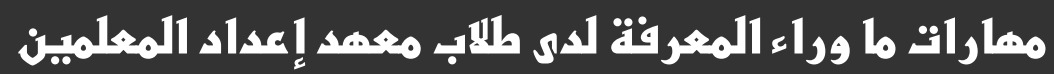

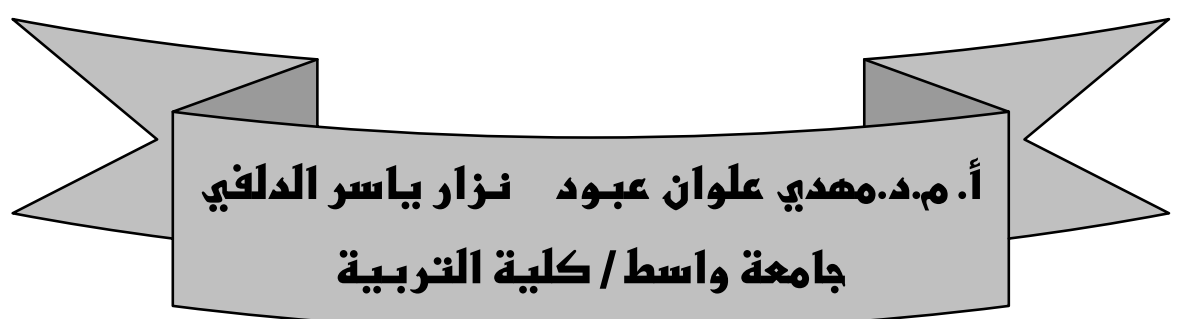

هشكانة البحث:

تتمثل مثكلة البحث في وجود ضعف في تفكير الطلاب لاعتماد المدرسين على طريقة

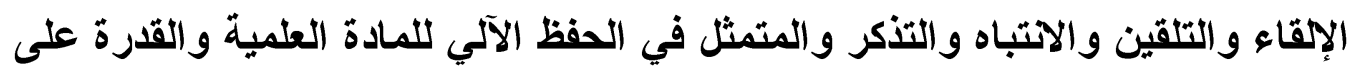
استرجاعها في الوقت المناسب مع إهمال العمليات العقلية التي تضم الأاكرة و التفكير والاتتباه

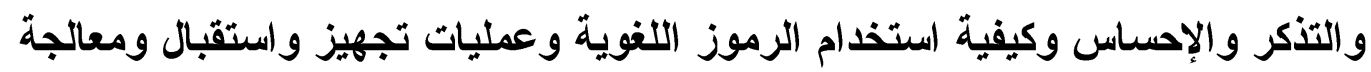

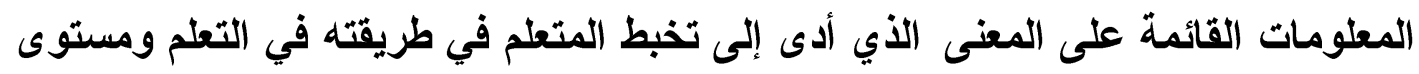

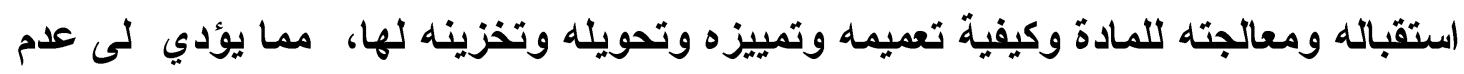

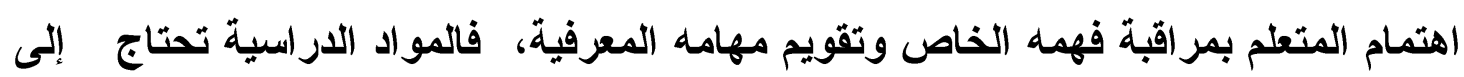

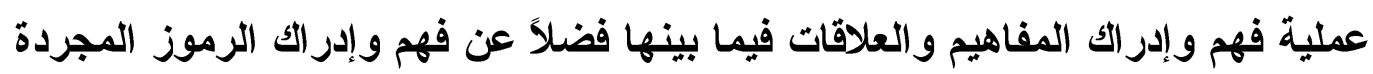
ومعنى المصطلحات العلمية وهذا بلدره يحتاج من المتعلم إلى وعي بمهار ات ما وراء المعرفة

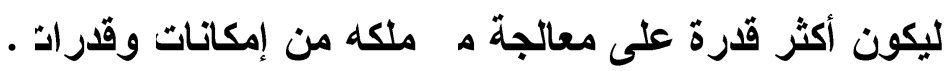

وقد شعر الباح ان بهذه المشكلة من خلال ممارسته ما لمهنة التدريس : ومن خلا

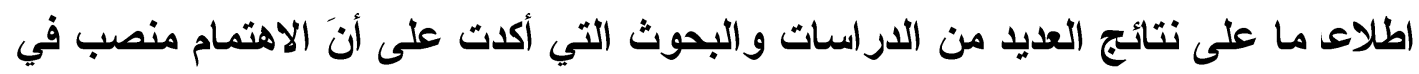
مهارات التفكير الانيا وإهمال المستويات العليا ل لتفكير كالتحليل ، والاستنتا: ، والربد ، و إصدار

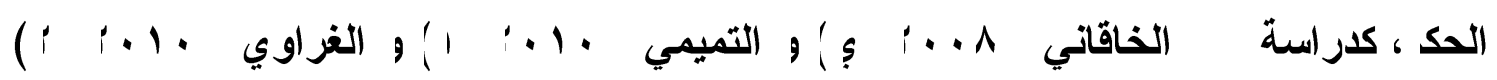

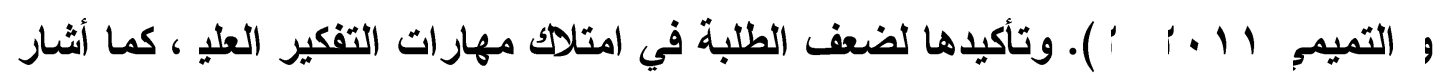
تايم روبرت من الناسر ، فالبعض يفكر بطريقة كلاسيكيا ، ولقد صارت الحاجة ملحة إلى الخروج من اعتماد Time,R,1988: التط واحد في التفكير والتوجه نحو اكتساب مهارات متطورة في التفير 


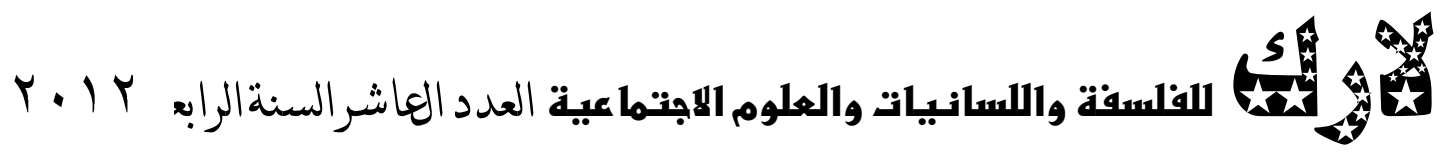

133 ) . وهذا ما أكده عدد من المشرفين والمتخصصين التربويين ، الأين عمد الباح ان إل ى الاتصال بهم للاستفسار عن هذه الظاهرة والاستعلام عن السبب الذي يقف وراعه ـ. ويمكن تلخيص مشكثة البحث الحالي من خلال طرح التساؤل الآتي : هل يمتلك طلاب معهد إعداد المعلمين مهار ات ما وراء المعرفة مئه من مئه

\section{أهميهية البحث:}

يحتل العقل في الفكر الإسلاهي مكانة عالية بوصفه أداة العلد ، ومعجزة الإسلام ( القرآن

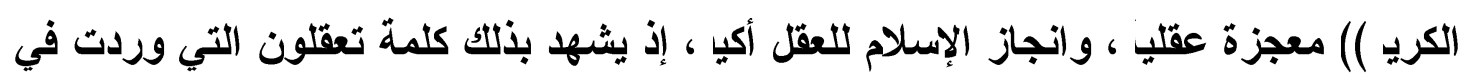

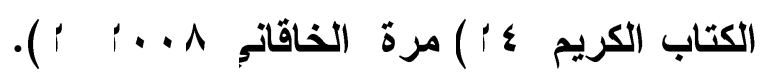

ومفهوم العلم في الإسلام يتسم بالثمول ، وهو كل معرفة منظمة يصل إليها الفكر الإنساتي من الإلهام والنظر والتأمل والملاحظة والتجريب والتعامل مع ظواهر الحياة - طبيعية

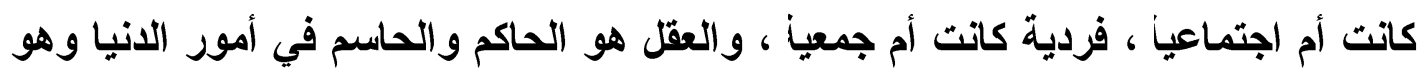

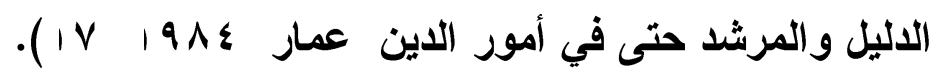
ويكفي أن نعرف عدد الآيات القر آنية التي وردت فيها مشتقا ت العقل ووظائفا ، والدعوة لاستعماله حتى نتوصل إلى نتيجة حتمية حول أهمية التفكير في حياة الإنسان عبد الباقي، .$(1) 199 \varepsilon$

إنّ معلم اليوم أصبح له أدوار متعددة، لكونه محفزاً ومشجعاً على النمو والتعلم، وعاملاً

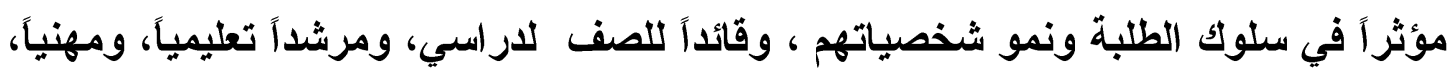

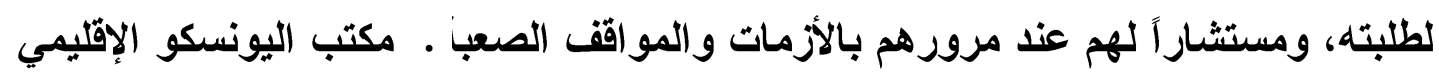

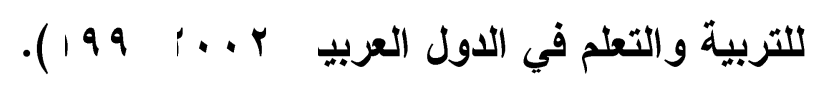

ويحدث التعلم بعدة طرائق ، فهو قد يتضمن حدوث تغيير في السلوك أو في التفكير أو

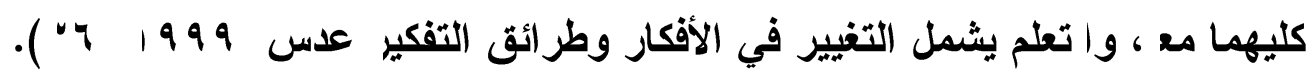
والتعلم هو مهارة ذهنية أو قدرة عقلية يمكن تنميتها أسوة بجميع القدرات الأخرى، و التعلم الجيا هو الأي يحفز قدرة الفرد على اكتساب الخبرات واستخلاص الحقائق بنفسه، ولا

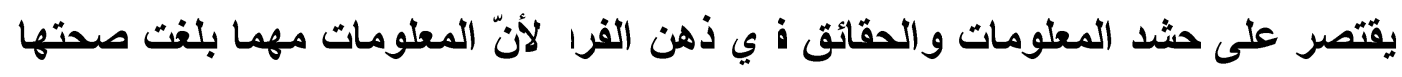
فمصيرها إلى النسيان والزوال وإنّ عجلة التقدم العلمي تأتي بغيرها، وتصبح غير نافعة، لألك 


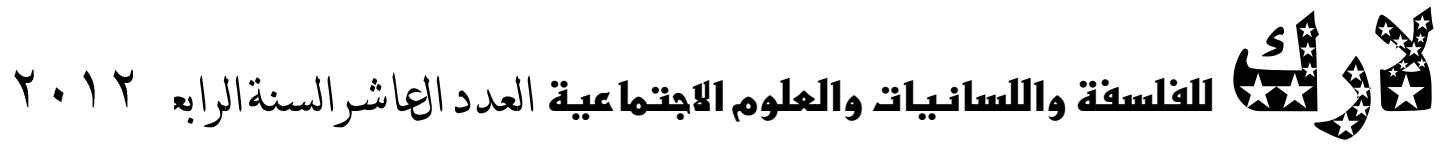

فإن هدف التعلم هو تنمية قرات المتعل ، بل تنمية شخصية بسائر سماتها وخصائصها

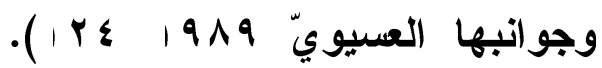

إذ يختلف طلبة ال وم عن طلبة الأمس في آمالهم وأهدافهم وتوقعاتهم، فهناك في الوقت الحاضر تأكيد ضرورة ربط التعلم بفهم المشكلات الثخصية والاجتماعية للفرد ومساعدته على

مواجهة الغزو العلميّ والتكنولوجيّ الهائل، وتمكينه من الاستفادة بأقصى درجة ممكنة، مّّا

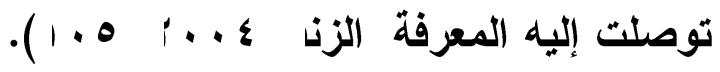

إنَّ التفكير هو أرقى أثكال النشاط العقلي عند الإنساز ، وهو الهبة العظمى التي منحها الله تعالى للإنساز ، وفضله على سائر مخلوقاته والحاضرة الإنسانية هي دليل على هذا التفكير

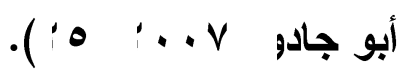

فقد حظي التفكير كعملية معرفية بعناية علماء النفس، إذ تنامى الاهتمام بالعمليات

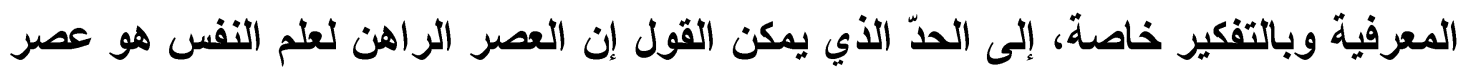

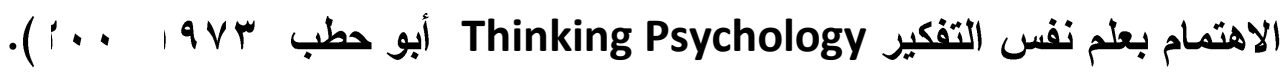
وبذلك أصبح من حق الطلبة على مجتمعهم على مثقفي مجتمعهم تسليحهم بهذا

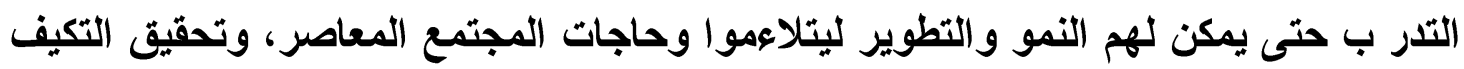
السوي لايهم، وبذلك أصبح من مهمات المجتمع المعاصر تدريب أبنائه على مهارة التفكير

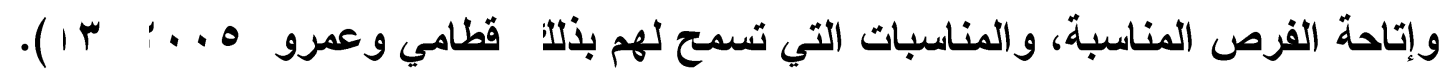
من هذا الواقع تبرز أهمية تعلم مهارات التفكير وعملياته التي تبقى صالحة مهما كان نوعها، ويشير الباحثان (iternberg and Quimby ) لهذه الحقيقة بقولهما (( إنّ المعارف مهمة بالطبع ولكنها غالباً ما تصبح قديمة، أما مهار ات التفكير فتبقى جديدة أبداً، وهي تمكنتا

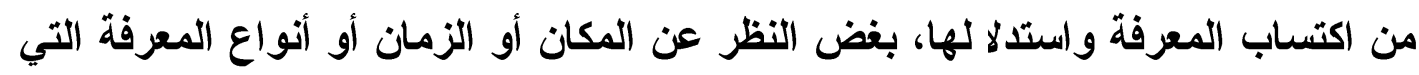

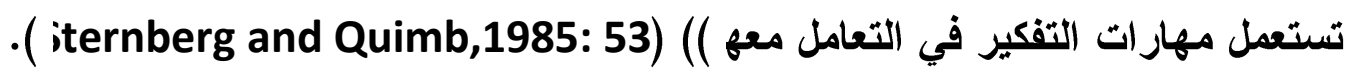
إنّ من أهم سمات التفكير القدرة على الآفتاح العقلي، فالإنسان بحاجة إلى معرفة

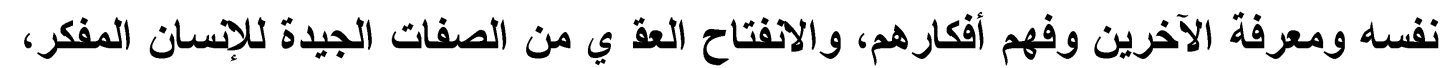

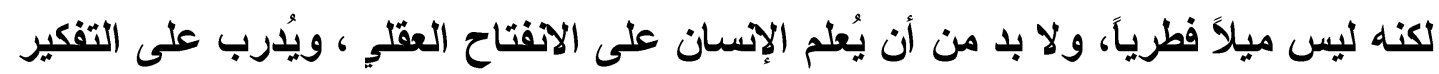
ليتعرف على الآخرين ويفهم مقاصده ـ وهنالك عدة طر ائق لتدريب الطلبة على رؤية خبرات الآل 


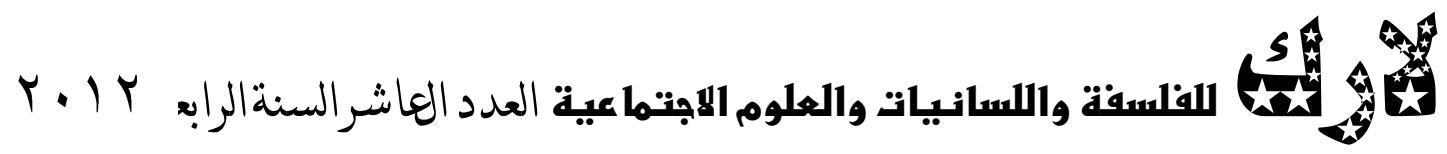

الآخرين، وفهم وجهات نظرهم، منها حلقات الاروس حول مو ضوعات مختارة من دروس

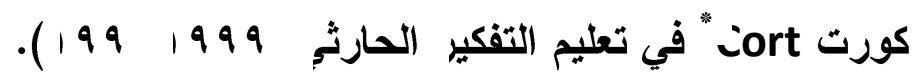

إنّ التفكير ما وراء المعرفي يتضمن مجموعة من العناصر التي تثكل بنية هذا

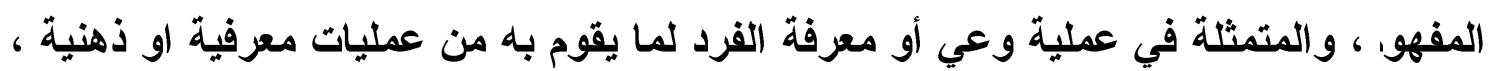

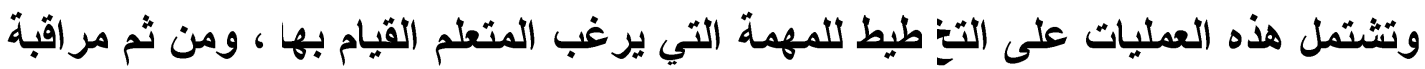

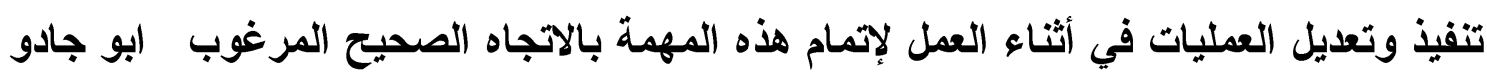

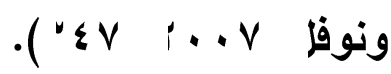

وقد أكد ذلك الكثير من الاراسات والبحوث التي دعمث أهمية ما وراء المعرفة فيما

يخص النمو المعرأ ي والتعلم الأكاديمي بصفة عامة، إذ يمكن زيادة فاعلية المتعلم بجعله أكثر

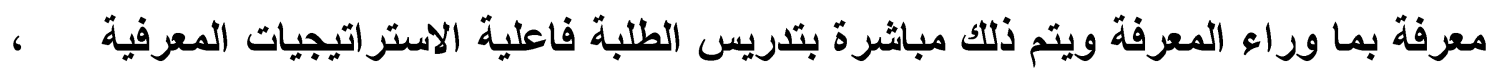
1990 Paris ( ومناقشة الجوانب والا(فعية للأشطة المعرفية كالتفكير، ويذكر باريس وونجرد

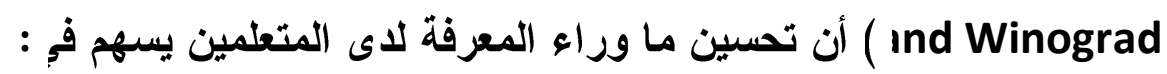
• تزويدهم باستبصار ذاتية عن تفكيره ـ

• تحقيق استقلالية التعلم مما يفيد في نقل مسؤولية التعلم من المعلمين الى التلاميذ أنفسه • • تكوين معتقدات ذاتية وانفعالات إيجابية لاى التلاميذ علاوة على الاور الافعي لذلك

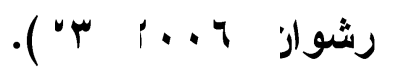

إن مهار ات التفكير ما وراء المعرفية تنمو ببطء بدأ من سن الخامسة ثم تثظور بنمو

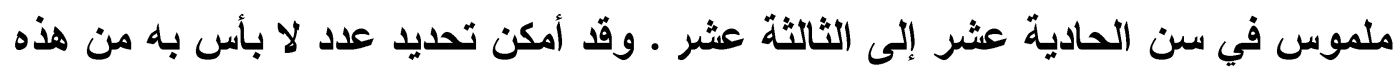
المهارات وقياسه ـ وأظهرت الار استات أن المفكرين والخبراء في حل المشكلات والقارئين الجيدين يته فون بأنهم يمتلكون سيطرة وقدرة على التحكم في تفكيرهم وتوجيهه كما أنهم يعرفون حدودهم، ويميزون بين ما يعرفونه وبين ما لا يعرفونه ـ فأنهم يعرفون هدفهم وكيف

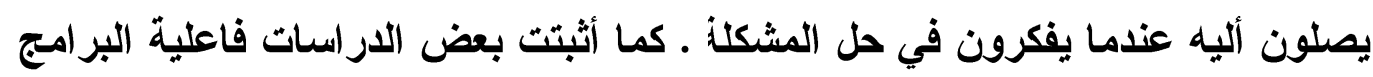

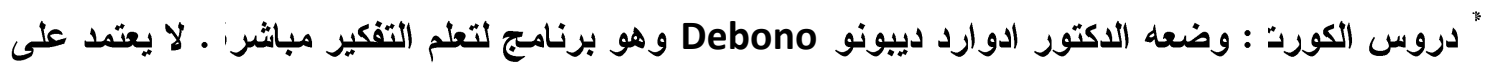

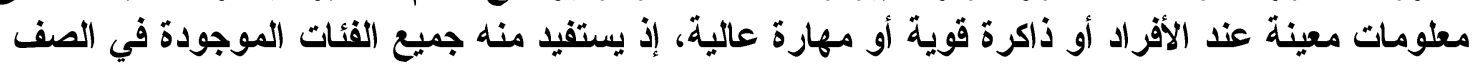

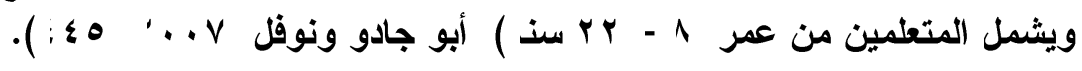




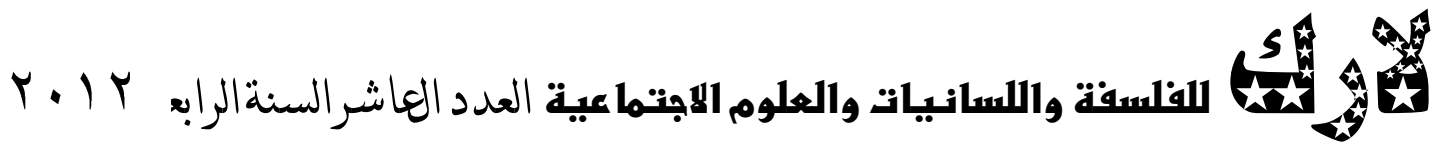

التعليمية لمهارات التفكير ما وراء المعرفية في تحسين مستوى وعي الطلبة بقدراتهم وكيفية Analogical استعمالها ومتى تستعمل، وأظهرث حدوث تحسن في مستوى الاستدلال التمثيلي Reasoning ومستوى الاستيعاب القرائي والشفوي (56-270! : 3arell , 1991 ). وتختلف عمليات ما وراء المعرفة من فرد إلى آخر تبعاً للظروف المرتبطة بعوامل النمو والنضج

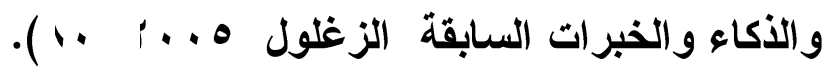
فهنالك كثير من البرامج التي تركز على التفكير كموضوع قائم بذاته، وعلى تعليم مهار ات التفكير ما وراء المعرفي، التي تسيطر على العلميات المعرفية وتديرها ومنها، التخطيط والمراقبة و التقوي ـ وتهدف إلى تثجيع الطلبة على التفكير حول تفكيرهم Thinking about thinking)

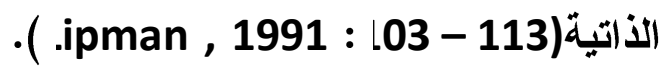

وهنالك دراسات كثيرة أكدات أهمية التفكير ما وراء المعرفي، منها ما ظهر من خلال

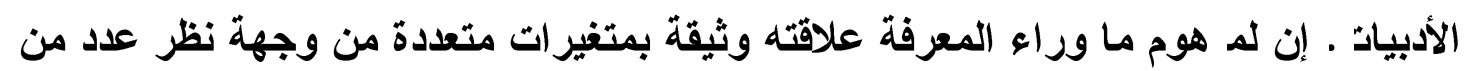
الباحثين وكذلك نتيجة الاهتمام المتزايد في تنمية وتعليم التفكير ما وراء المعرفي أتجه عدد مند من الباحثين إلى بيان أهمية التفكير ما وراء المعرفي أكثر أهمب : الار اسة التي قام بها روماتفيل (Romaniville و (التي هدفت إلى التحقق من طبيعة العلاقة بين كل من التفكير ما وراء المعرفي والتحصيل الدراسي أثـارث نتائج تلك هل الار اسة التي تم إجراؤها على ه ه• ) طالباً جامعياً من مستوى السنة الار اسية الأولى بكلية

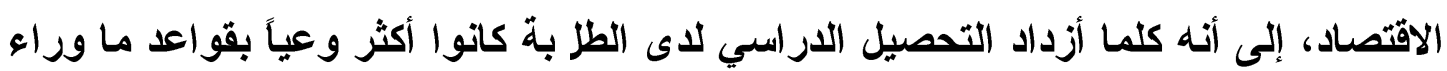

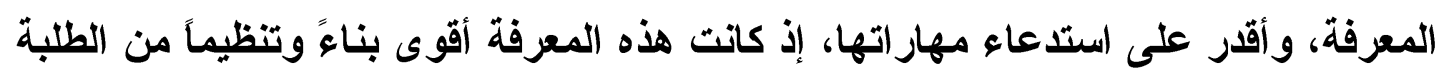

الأقل تحصيلا (Romainville,1994; 359-366 ).

لذلك فقد نادى كثير من التربويين بأهمية يقظة الفرد ووعيه لما يوظفه من استراتيجيات

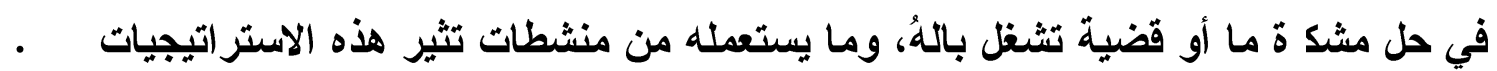
و أكدوا من ناحية أخرى أهمية ضبط الفرد المتعلم لعملية تعلمه وتحكمه بها، وتوجيهه الوجهة الصحيحة المنوط بها، فهم يعتقدون بأهمية المتعلم مستقلاً في تفكيره وان يكون قادراً على توجيه عملياته لعقلية وعملية تعلمه الوجهة التي تؤدي إلى تحقيق الهدف المنشود، كلما كان الفرد واعياً بالاستر اتيجيات التي يوظفها في تعلمه متحكماً بها ضابطاً لها أدى ذلتك إلى نتائج

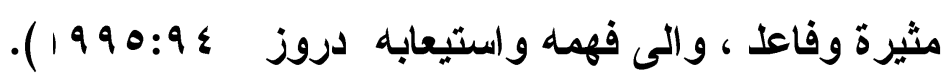




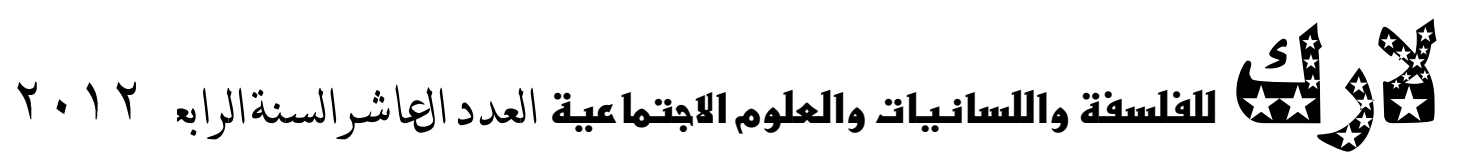

ومما تقدم تبدو أهمية البحث والحاجة إليه من خلال ما يأتر :-

ا أهمية المعرفة في حياة الطلب .

r أهمية تعلم الطلبة كيف يفكروز r

r م أهمية التعرف على مهار ات ما وراء المعرفة للطلبة

ع مساعدة العاملين في ميدان التربية والتعليم على تنمية مهار ات ما وراء المعرفة للطلب .

ه أهمية معرفة الطلبة بمهار ات التفكير ما وراء المعرفح .

צ تعرف العاملين في ميدان التربية والتعليم ولاسيما المعلمين بأهمية دور إستراتيجيات التعلم وتطبيقها في مدارسذ .

هدف البحث:

$$
\text { يهدف البحث الحالي التعرف على : }
$$

مهار ات ما وراء المعرفة لاى طلاب معهد إعداد المعلميز .

هدود البحث:

يقتصر البحث الحالي على طلاب معهد إعداد المعلمين، الدراسة الصباحية في محافظة

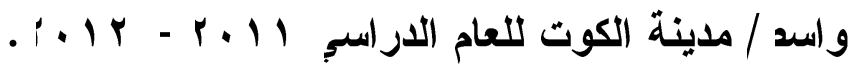

تهديد المصطات:

$$
\text { مهار ات ما وراء المعرف : }
$$

عرفه 1996 DRISCOLL

وعي الطالب بعملية التفكير ذاتها وقدرته على الاتخر اط في سلوك منظم ذاتياً،

ويتضمن ذلتك مهار ات معرفة ما يـ رفه الطالب وما لا يعرفه والتتبؤ بدقة الإجابة أو صحتها

و التخطيط للمستقبل،والتحقق من نواتج الحلول التي يقدمها الطالب ومر اقبته , $1996: 89$

V. 


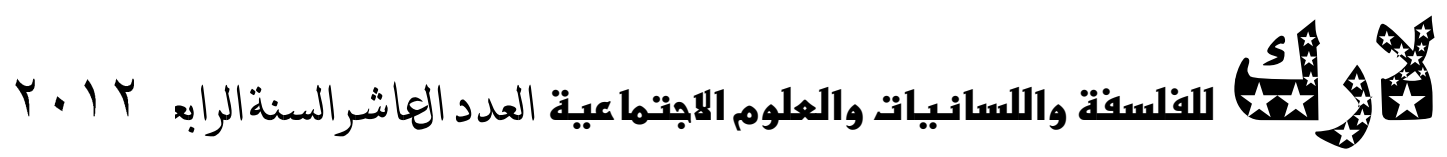

عرفه : جرواز 999 19 ، بأنه :

مجموعة من المهار ات العليا التي تقوم بإدارة نشاطات التفكير عندما ينشغل الفرد في وقف حل المشكلة أو اتخاذ قرار وقد صنفت في ثلاث فح ت رئيسة هي التخطيط والمراقبة

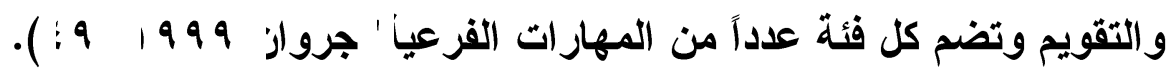

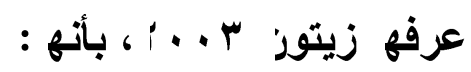

هي عمليات تحكم وظيفتها التخطيط والمر اقبة و التقويم لأداء الفرد في حل المشكلة

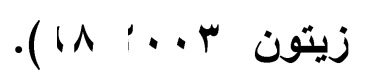

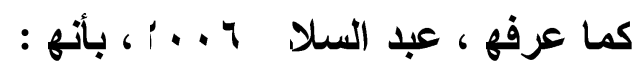

هي إتاحة الفرصة للطالب للتفكير الواعي في المهمة أو العمل ووضع خطة لها و إدراكها والتحكم فيها،إلى ما بعد معرفته عن الواقِ ومراقبة أداؤه وتقويمه و إنتاج أفكار أكثر عمقاً واتساعاً،وذلك من خلال مواقف تعليمية تسمح لله بالنشاط والحرين" عبد السلام $\cdot(1 \cdot .7$

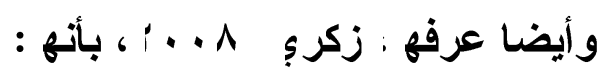

هي المعلومات التي يمتلكها الفرد عن عملياته المعرفية والإستراتيجيات التي

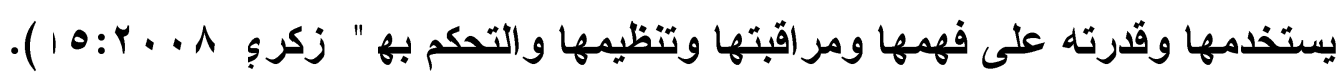

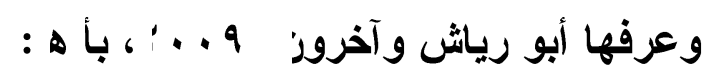

هي قدرة الفرد على معرفة ما يعرف وما لا يعرف وقدته على تخطيط إستر اتيجية من

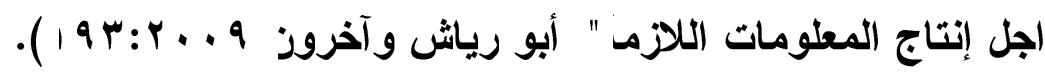

$$
\begin{aligned}
& \text { التعريف النظري : يتبنى الباحث تعريف زيتوز . . ). }
\end{aligned}
$$

التعريف الإجر ائج : هي مهارات عقلية تتضمن المعارف الثرطية والتقريرية والإ جرائية

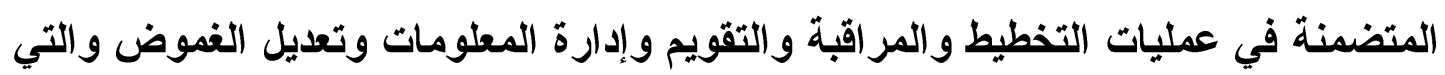
يـ تعه ها طلاب معهد إعداد المعلمين أثناء در استهم لمادة علم نفس الطفل ) ضمن مدّة البحث وتقاس بالدرجة التي يحصل عليها الطلاب عند الإجابة على مقياس مهارات ما وراء المعرف ة الأي تبناه الباحث في هذا البحث. . 


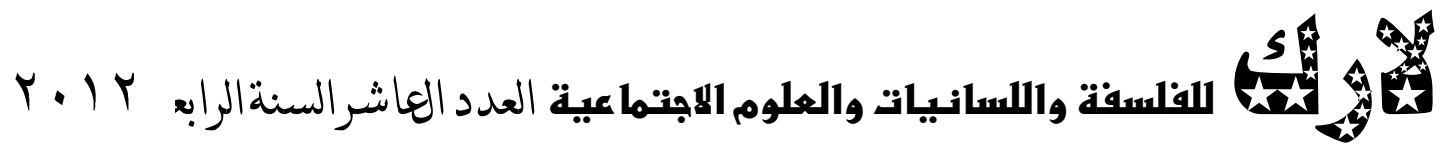

معهد إعداد المعلميز

عرفته وزارة التربية سنا 9AV 9 بأنه مؤسسة تعليمية مهمتها إعداد معلم أو معلمة

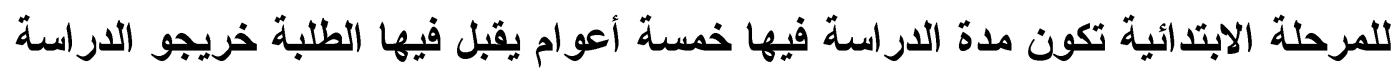

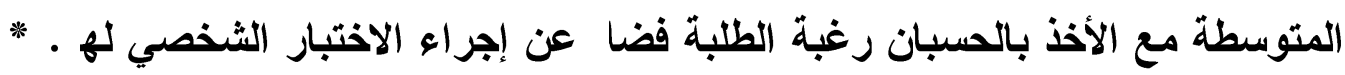
كما عرفه المؤتمر الاولي للتربية بأنه مؤسسة تربوية لإعداد معلمين ومعلمات

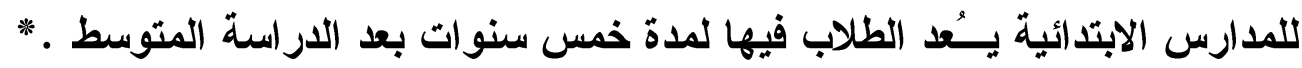

جمهورية العراق ، وزارة التربيا كراس صادر من المديرية العامة للاعداد والتا ريب ، مطبعة

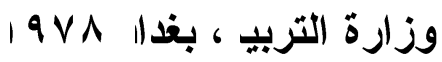

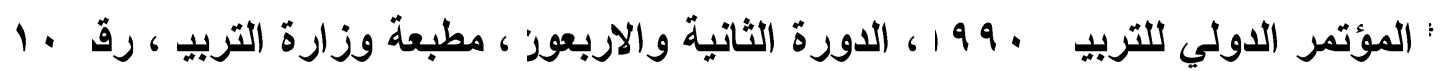
مهار مات ما وراء المعرف :

، إن الجذور التاريخية لهذا المفهوم قد ترجع إلى سقراط وأسلوبه في الحوار والجدل

146 ) ثم إلح, أفلاطون حيث قال (( حينما يفكر العقل فانه يتحدث

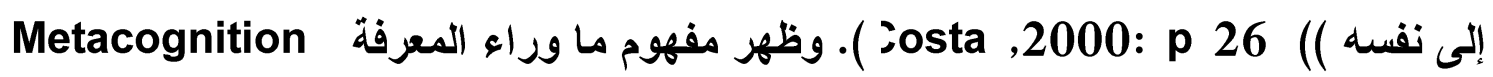
التفكير في التفكير الميتا معرفية ) في بداية السبعينات ليضيف بعدا جديدا في علم النفس

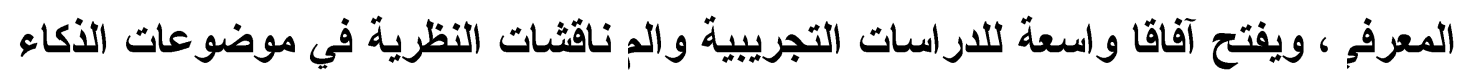

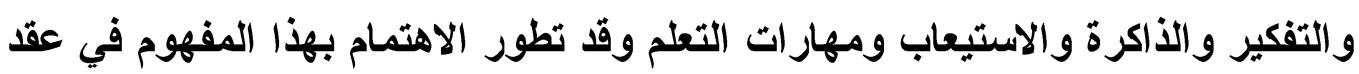
الثمانينات ولا يز ال يلقى الكثير من الاهتمام نظر الارتباطه بنظريات الأكاء والتعلم

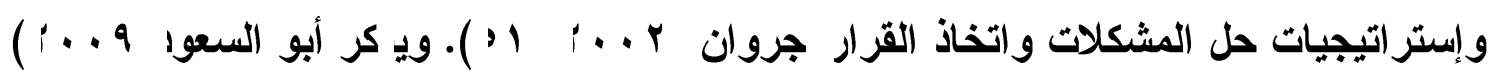
أن فلافل أول من استخدم مصطلح ما وراء المعرفة Metacognition في البحث التربوي، وقد لاحظ فلافل إن الأفراد يقومون بعملية مراقبة لفهمه الخاص و الأشطة المعرفية الأخرى أي إن ما وراء المعرفة تقود الطلاب للاختيار، و تقوم المهام المعرفية و الأه

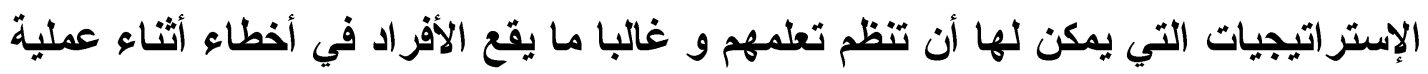
التعلم نتيجة لإخفاقهم في ذلك لأ يجب أن يقوم الطلاب بالاستفادة من هذه العمليات في تحديا 


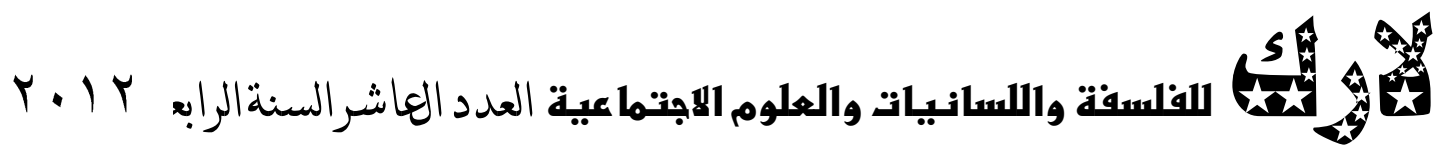

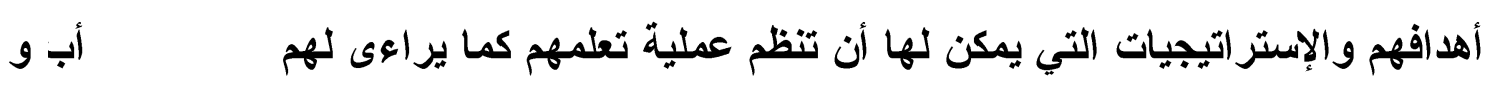

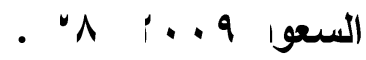
طبعة ما ور اهو المعرف

يعد مفهوم ما وراء المعرفة Metacognition واحدا من التكوينات النظرية المعرفية المهمة في علم النفس المعرفي المعاصر ، وقد ظهر هذا المفهوم على يد فلافل Flavell ولقي Braown اهتمامـا ملموسا على المستويين النظري والتطبيقي، وقد أج رى عليه براون تطبيقات متعددة في مختلف المجالات الأكاديمية و توصل من خلال هذه التطبيقات إلى الأهمية

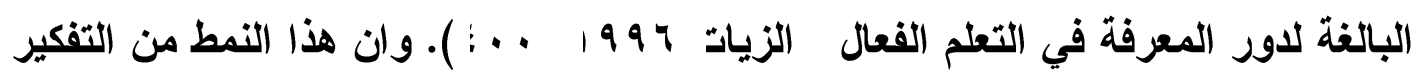

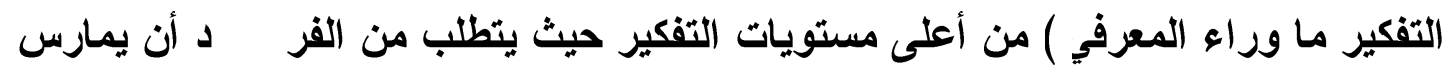
عمليات التخطيط و المراقبة و التقويم لتفكيره بصورة مستمرة كما يعد شكلا من أثكال

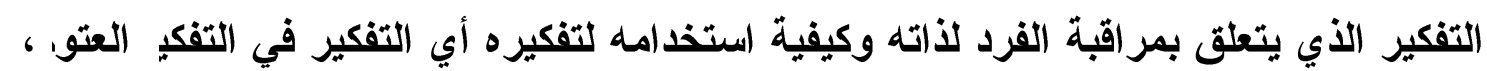

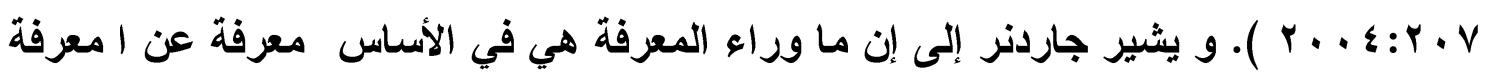
فإذا كانت المعرفة تتضمن الإدراك والفهم والتذكر فان ما وراء المعرفة تتضمن التفكير في

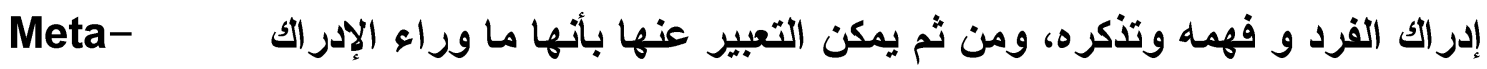
) و ما وراء الفهم Meta-comprehension ) و ما وراء الذاكرة Meta-memory والتفكير في ما وراء المعرفي هو مهارات عقلية معقدة تعد من أهم مكونات السلوك

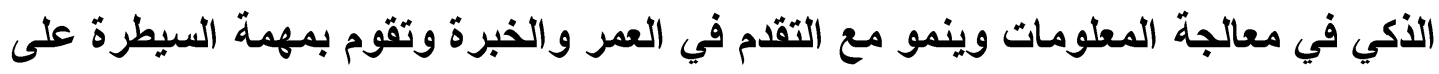
جيع نشاطات التفكير العاملة الموجهة لحل المشكلة باستخدام القدرات المعرفية للمفردة

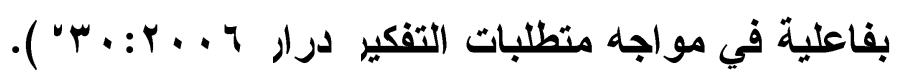
تصنيف مهار ات ما وراء المعرف تصنيف أبو رياش، وغسان 1 . ) ): فقد بينوا إن مجموعة مهارات ما وراء المعرفة تتخذ شكلاً عنقودياً مرتبطاً بعضها ببعض ومرثبّة بطريقة منف مة،وتترتب هذه المهار ات تحت ثلاث مهار ات أساسية هي كالأتج : 


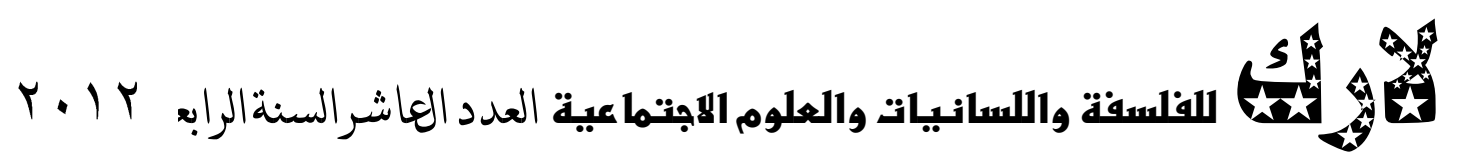

أو! مهارات التظظيم الأتح : وتنكون مز : - الالتز ام بأداء مهمة علمية معيذ .

- الاتجاه الايجابي نحو المهمة العلمب -

- السيطرة على الاتتباه لمتطلبات المهمة العقلي .

ثانيا :. مهارات توظيف المعرفة لأد ع المهمة العلمي : وتتكون مر :

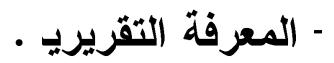

- المعرفة الإجرائي

ثالثة :. مهار ات الضبط الإجرائح : وتتكون مز :

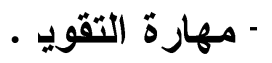

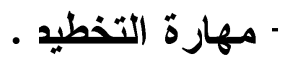

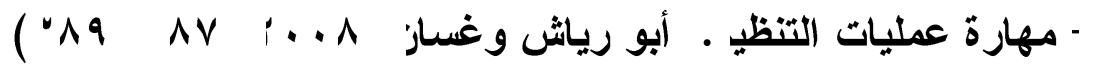

الدراسات البسابقة

ا - دراسة يور و كريج (1992 ) ('ore \& Craige ).

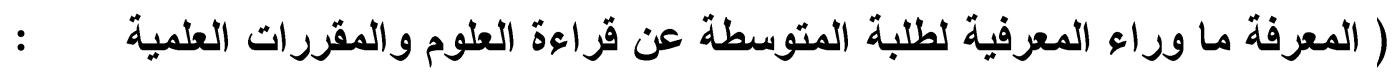

تقييمات موضوعية، دقيقية، ونتائج )(اعل.

رمت الار اسة تقصي وعي طلبة المرحلة المتوسطة لقراعة العلوم ومدى امتلاك الطلبة

لأنماط المعرفة ما وراء المعرفية الثلاثا : التقريرية والث رطية والإجر ائية المتعلقة بهذه ومئه

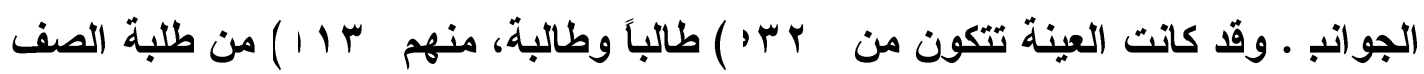

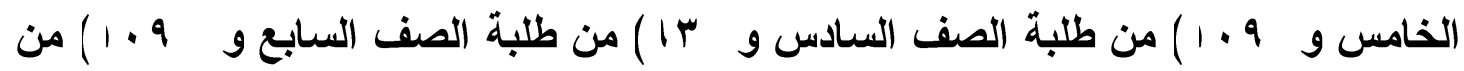
طلبة الصف الثامر . مامن و من

وقد استعملا اختبار من نوع الاختبار المتعدد من م با، ) فقرة تقيس جواتب المعرفة

الثلاثة المتعلقة بـ 1 1 ) صفة من الصفات التي يجب أن يتحلى بها القارئ الجيد في العلوم . أما الوسيائل الإحصائية فهي اختبار توكي ومربع كاب . 


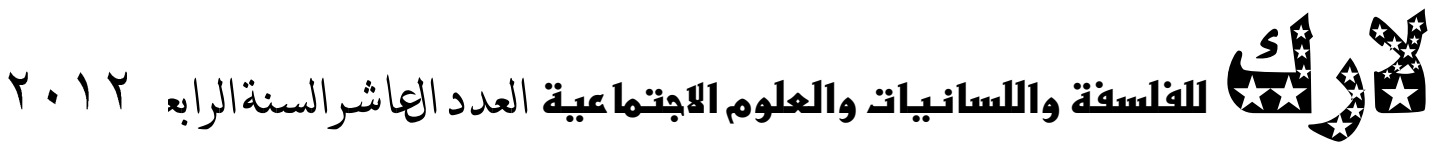

وقد أظهرث التتائج أن هناك ضعفاً عاماً في معلومات الطلبة في المجالات الثلاثة المذكور ، وان هناكك فروقاً د الة إحصائيا بين الطلبة ذوي القدرة القرائية العالية والطلبة ذوي فعائي القدرة القرائية الضعيفة في مستوى امتلاك المعرفة ما وراء المعرفية وان الإناث لايهن معرفة ما وراء معرفية في القراعة العلمية والكتب المقررة في العلوم أكثر من الأكور وان

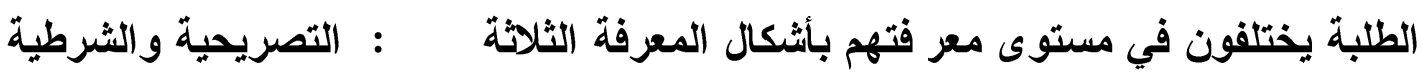
والإجر ائي ) (3) - ( 'ore \&Cralge , 1993: i0 r - دراسة موكتاري وريتشارد ( Mokhtari and Reichard 2002 ) (( تقويم وعي الطلبة ما وراء المعرفي في استراتيجيات القراهة )).

طور الباحثان موكتاري وريتشارد ( Mokhtari and Reichard 2002 ) مقياساً

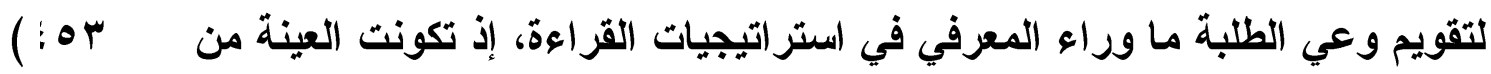
طالباً والطلاب يمثلون الصفوف من السادس حتى الصف الثاني عشر، أسفرث نتائج التحليل ألعاملي لأبعاد المقياس عن وجود ثلاثة عوامل رئيسة هي : البعد الأول : استراتيّ يات القراعة الشاملة (jlobal Reading Strategies ، وقد تكون هذا البعد من ب ا ) فقرة ، والبعد الثانج : استر اتيجيات حل المشكثة (rob;em Solving Strategies' ) وقد تكون هذا البعد

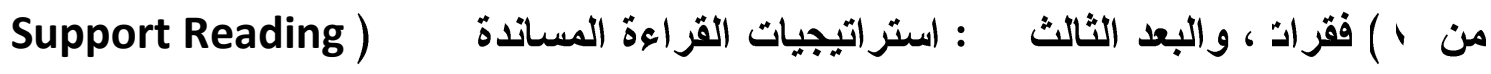

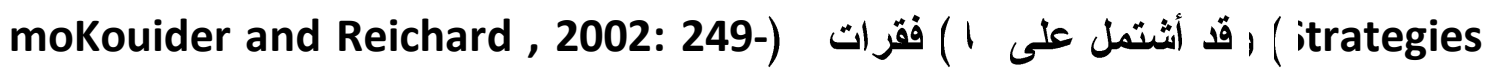

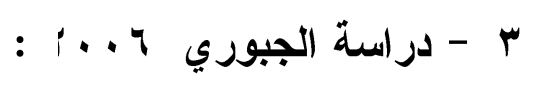

( قلق الامتحان وعلاقته بالمهار ات ما بعد الم رفية لاى طلبة ثانويات المتميزيز )). رمت دراسة الجبوري ج . ) قياس قلق الامتحان تبعاً للجنس والمرحلة والى إيجاد دلاكة الفروق في قلث الامتحان تبعاً للجنس والمرحلة وقياس المهارات ما بعد المعرفية لعينة البحث وقياس المهارات ما بعد المعرفية ومدى امتلاك الطلبة لهذه المهارات وتعرف العلاقة الارتباطية بين قلث الامتحان ومهارات ما بعد المعرفة ـ تكونت عينة البحث من طلبة الصفوف الصف

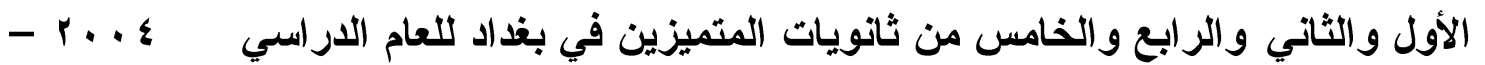

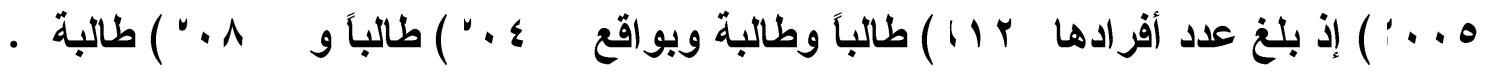

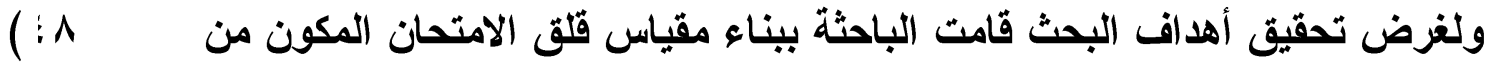




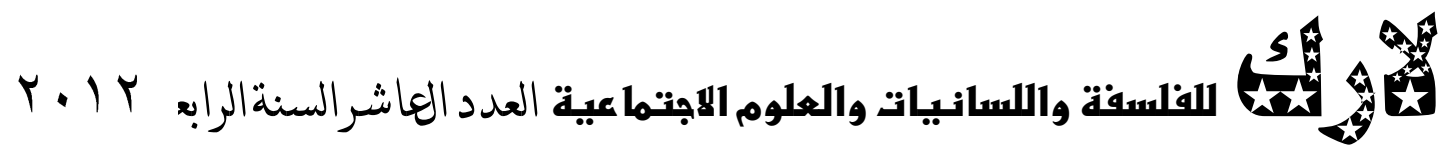

فقر ، وكذلك بناء اختبار مهارات ما بعد المعرفة المكون من ع د ) فقرة ، وقد استعملت الباحثة مربع كاي والاختبار التائي لعينتين مستقلتين ومعامل ارتباط بيرسون ومعامل الفاكرونباخ والاختبار التائي لعينة واحدة والقيمة التائية لالالة معامل الارتباط كوسائل إحصائية للوصول إلى نتائج البحث: .

وقد أسفرت نتائج البحث أن متوسط درجات عينة البحث على مقياس قلق الامتحان

أعلى من المتوسط ، أي أن عينة البحث لايها قلق امتحان بمستوى أعلى من المتوسط ، وأن

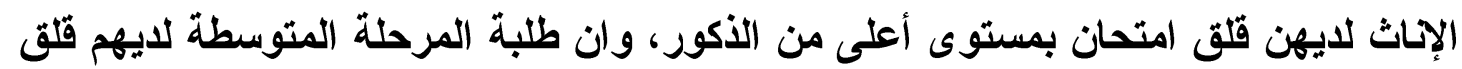

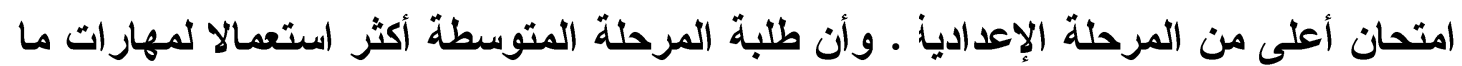
بعد المعرفة من طلبة الإعداديا: ، وان هناك علاقة أرتباطية موجبة دالة إحصائيا بين قلق

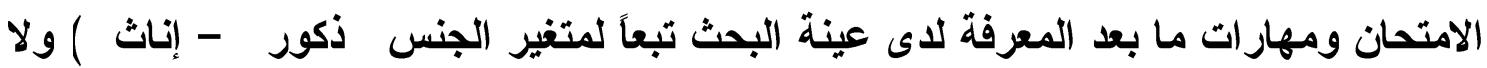
توجد علاقة أرتباطية بين قلق الامتحان ومهارات ما بعد المعرفة لاى عينة البحث تبعاً لمتغير

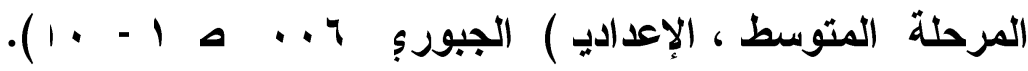

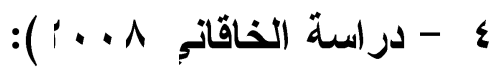

ستر اتيجيات ما وراء المعرفة لاى العاديين والمتميزين والموهوبين من طلبة المرحلة

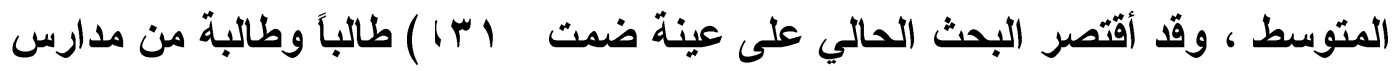

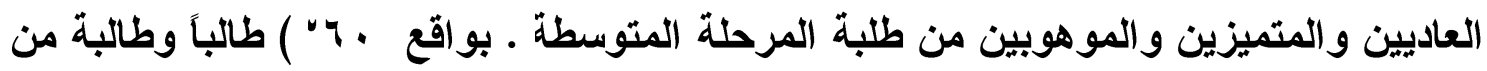

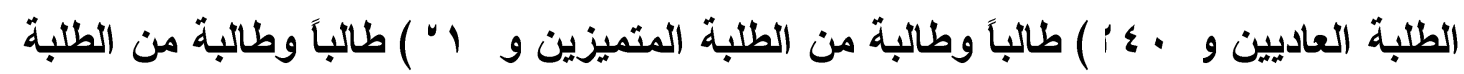

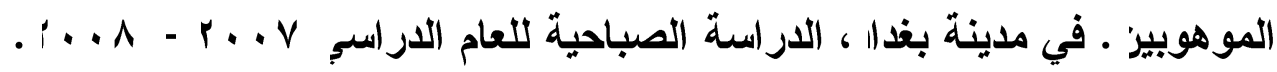
قامت الباحثة ببناء مقياس استراتيجيات ما وراء المعرفة ، والمتكون من 1 ) فقرة

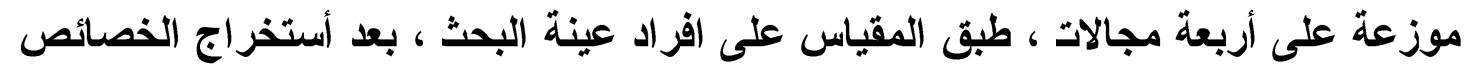
السيكومترية للمقياسر ، استعانت الباحثة في تحليل البيانات باستعمال الوسائل الإحصائية المن سب ، منها معامل ارتباط بيرسون واختبار مربع كاي والاختبار التائح . وقد أظهرث النتائج أز : ايتسم الطلبة الموهوبون بدرجة كبيرة باستعمالهم استر اتيجيات ما وراء المعرفة في

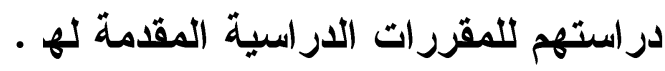




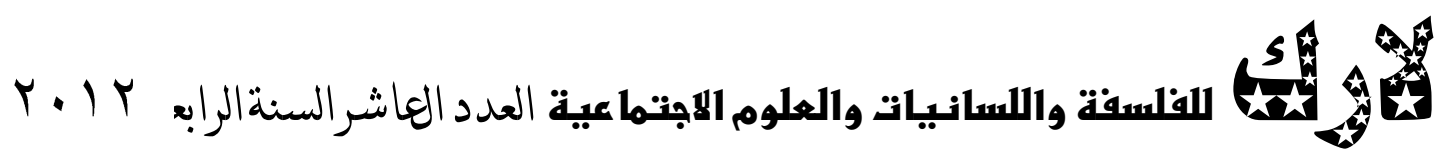

r يتسم الطلبة المتميزون باستعمال استر اتيجيات ما وراء الد عرفة بدرجة أقل من الطلبة الموهوبيز .

ب يتسم الطلبة العاديون بضعف استعمالهم لاستر اتيجيات ما وراء المعرفة في دراستهم

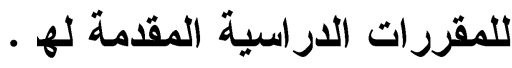

ع وجود فروق ذات دلالة إحصائية ولصالح الطلبة العاديين والمتميزين والموهوبين للعينة

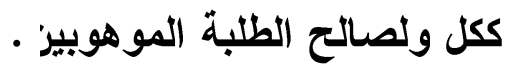
ه وجود فروق ذات دلالة إحصائية ولصاتح الطلاب الموهوبين والطالبات الموهوبات في

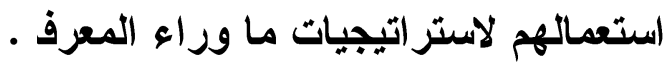

7

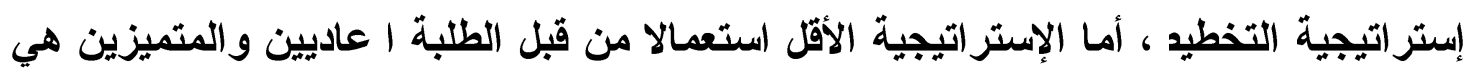

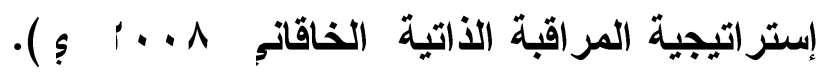

\section{جوانب الإفادة هن الدراسات السابقة:}

بعد اطلاع الباد ان على الاراسات السابقة في تحديد جواتب الاتفاق والاختلاف بينها وجد أن هناك جوانب يمكن الإفادة منها في هذه الاراسة سواء في تحديد المشكثة أم في إبراز الأهمية أم في بعض إجراعاته وعند تحليل النتائج على النحو الأتر :-

• إن جميع الار اسات استهدفت قياس مهارات ما وراء المعرفة وكذلك هذه الار اسة لتحديا هذه المهار ات لاى طلاب معهد إعداد المعلميز . ـ تناولت الار اسات مر احل دراسية متنوعة لمتوسطة والإعدادي ) لذلك ارتئى الباحث أن تكون الار اسة على طلبة معاهد إعداد المعلمين لقلة الار اسات في هذه المرحلة ولأهميتها في الواقع التربوي وبخاصة الصف الثالث إعدا / محافظة واسد ـ

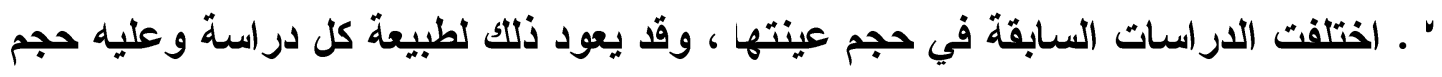

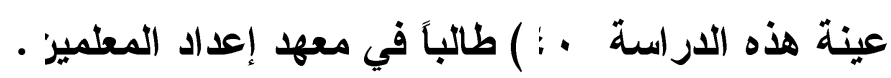
: ـ تناولت هذه الدراسة الأكور ) من طلاب معاهد إعداد المعلمين وهذا ما اتفق مع دراسة موكتاري و ريتشارا ). 


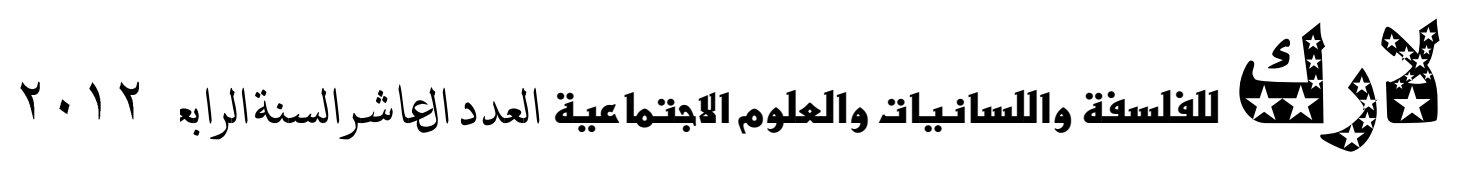

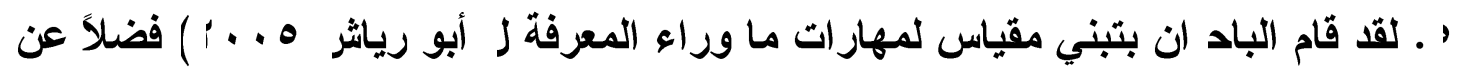
بناء اختبار تحصيلي، ولقد أفادت الدراسات ال سابقة الباحث في كيفية بناء الاختبار التحصيلي

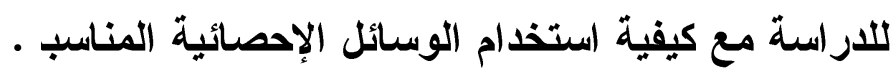

، ـ لقد وجد الباد ان في نتائج الار اسات السابقة ما يمكن الإفادة منه في تحليل نتائج هذه

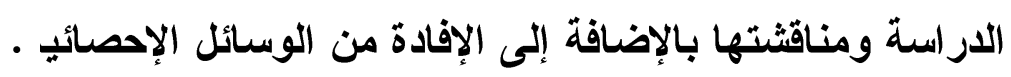
' ـ الإفادة من المه ادر العربية والأجنبي .

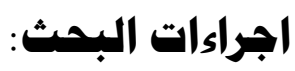

منهِج الإر اسد :

منهج الاراسة هو المنهج الوصفي، وهو من أكثر مناهج البحث استخداما ولا سيما في

مجال البحوث التربوياً إذ إن المنهج الوصفي يهتم بجمع أوصاف دقيقة وعلمية للظاهرة

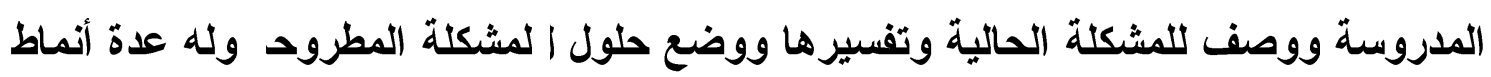
ومنها دراسات العلاقات المتبادلة التي تثمل الاراسات الارتباطين والتي تستخدم للتعرف على ولى

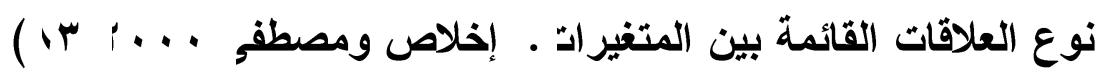

هبتمه البمث وعينته:

يشتمل مجتمع البحث جميع مفردات الظاهرة التي يدرسها الب حث أي جميع الأفراد أو

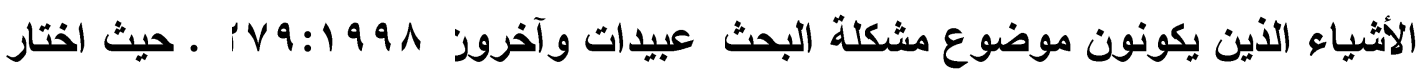
الباحث معهد إعداد المعلمين في مدينة الكود / محافظة واسط بصورة موريو قصدي .

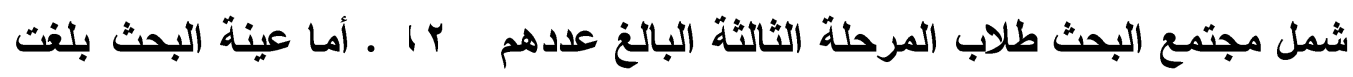

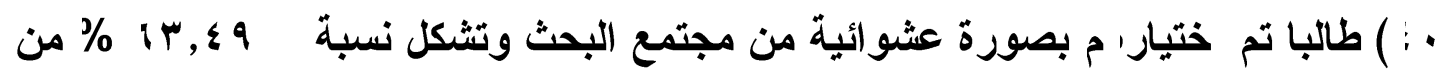

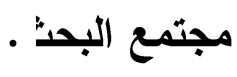

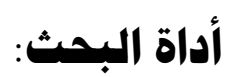
مقياس مهار ات ما وراء المعرف : 


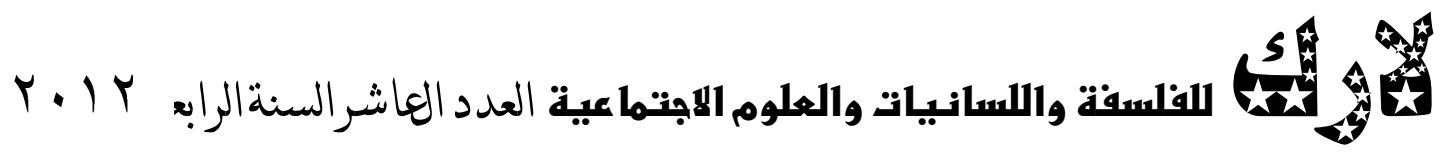

يتطلب البحث الحالي قياس مهارات ما وراء المعرفة لاى طلاب عينة البحث

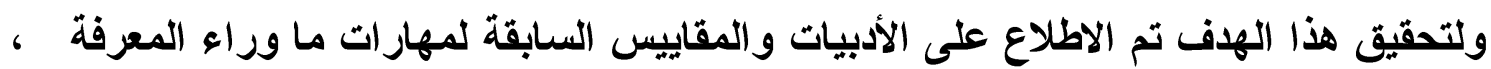

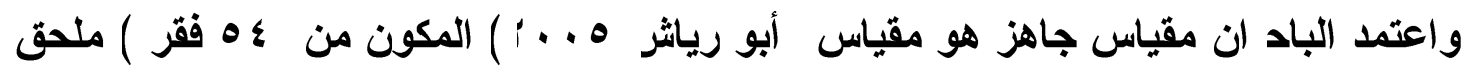

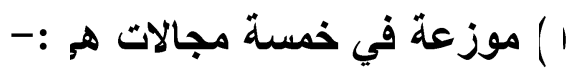

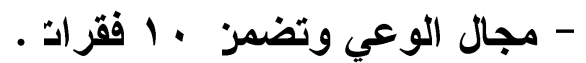

- مجال الاستر اتيجية المعرفي: وتضمز و فقراد .

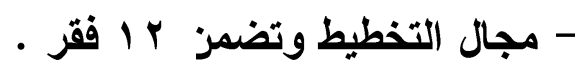

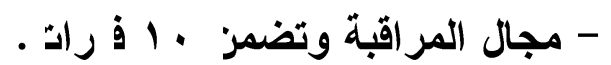

- مجال المر اجعة والتقويم وتضمز ب إ فقر

وبالرغم من المميزات التي تمتع بها المقياس من صدقه وثباته ارتأى الباحث القيام

ببعض الإجراعات قبل تطبيقه على عينة البحث إذ تشير الأدبيات إجراء صدق وثبات للمقاييس من من إذا مر على استخدامها أكثر من هنواد ، واتبع باد ان الخطوات الآتية من أجل اعتماد المقياسر :-

صدق المقياسر :- يقصد بالصدق قدرة المقياس على قياس الخاصية التي وضع لقياسها فع Ali, 1997: 113

وهناك عدة أنواع من الصدق اختار الباد ان الصدق الظاهري من بينها لقياس صدق

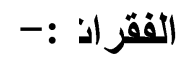

* الصدق الظاهر: :- التحقق من الصدق الظاهري للمقياسر : يعد اتفاق المحكمين نوعا من

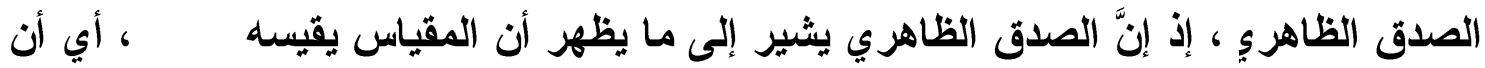
المقياس يتضمن فقرات إنها على صلة بالمتغير الأي يقاس ، وان مضمون المقياس متفق مع إن

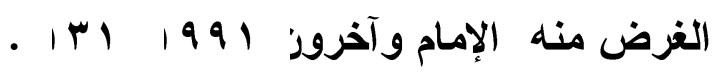

ومن أجل لتحقق من صدق المقياس عرضت فقراته على عدد من الخبراء

والمتخصصين التربوييز ، ليعطي كل منهم رأيه في فقرات المقياس ، ومدى انتماء الفقرات للمجال الأي وضعت فيه وحسن صوغه ومدى وملاثمتها لطلاب الصف الثالث / معاهد إعداد المعلميز ، و اقتراح التعديلات المناسبة وقد أعطى المحكمون ملاحظاتهم بثأن العبارات في 


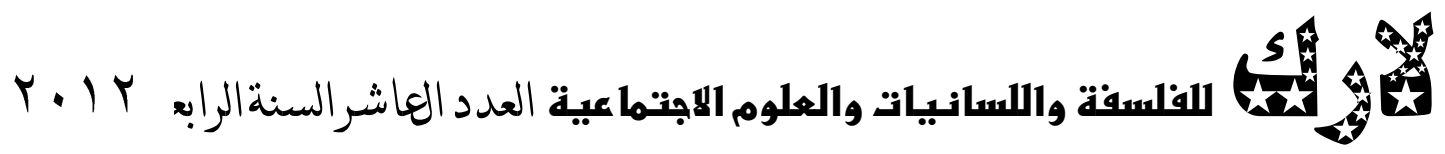

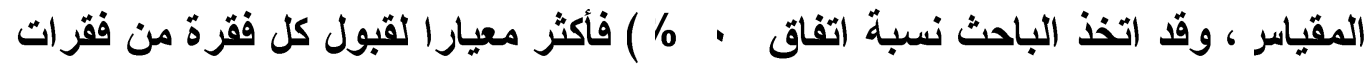
المقياسر ، إذ اتفق الخبر اء على تعديل بعض الفقرات وقد أخذ الباحث بالتعديلات والاقتر احات المناسبة وبذلك بقي المقياس مكونا من عه فقر ) دون حذف أي منه ـ وبهذا تم التحقق من

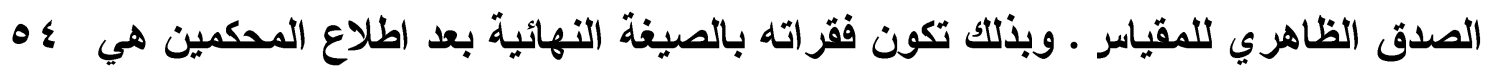
فํ

- ثبات المقياسر :- ويحصل ذلك من خلا إعادة تطبيق المقياس على المفحوصين نفسهم

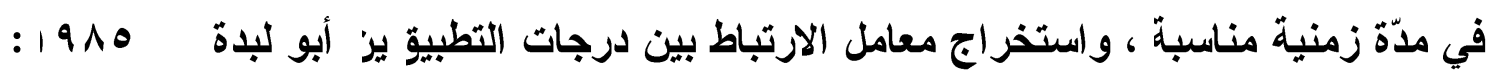
r

إدّ تم تطبيق المقياس على عينة استطلاعية تكونت من ب طالبة ) في معهد إعداد المعلمات في مدينة الكوت للمرحلة الثالثة أي بمرحلة العينة الأصلية نفسها للبحث ، وبعد مدّة ع ا يو، ) أعيد تطبيقه على العينة الاستطلاعية نفسها وباستخدام معامل ار تباط بيرسون بين درجات الطالبات في التطبيق الأول والثاني للمقياس ، حصل الباد ان على معامل ثبات المقياس ككل وبدرجة 027 ( ) وتعد هذه درجة ارتباط جيد .

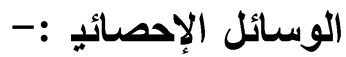

استعان الباد ان بالحقيبة الإحصائية للعلوم الاجتماعيذ spss لإيجاد ما أتج - ثبات مقياس مهارات ما وراء المعرفة باستعمال معادلة معامل ارتباط بيرسوز . - ثبات آراء المحكمين باستعمال معادلة نسبة الاتفاق لكوبر • - مدى امتلاك الطلاب لمهارات ما وراء المعرفة باستعمال الوسط المرجتِ .

\section{عرض النتائج وهناقشاتها:}

بعد الاتتهاء من عملية تطبيث أداة البحث واستج ابة أفراد العينة على فقرات الأداة

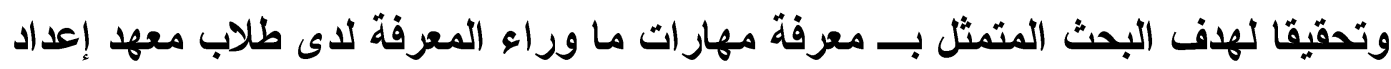
المعلميز .

قام الباحثان بتصحيح استجابات أفراد العينة وتفريغها في جداول خاصة لاستخراج تكرار كل بديل من بدائل الاستجابة واستخراج الوسط المرجح للك ل فقرة من فقرات أداة البحث $\Lambda$. 


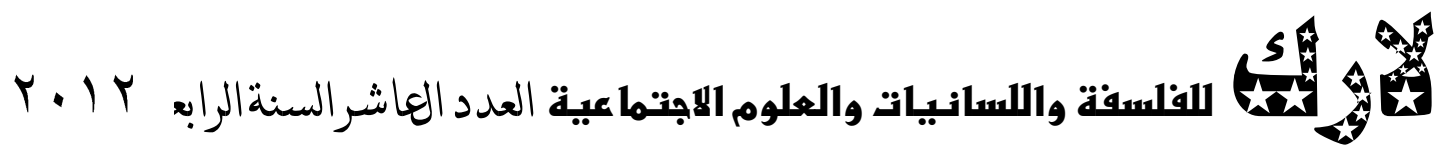

والتي تمثل كل منها مدى امتلاك طلاب معهد إعداد المعلمين لمهارات ما وراء المعرفة وبحسب المجال الأي تقيسه هذه الفقرات وكما يأتح .

- فقرات مقياس مجال الوعر : وتضمن ا ) فقرات رتبت تنازليا كما في جدول .

$$
\text { جدول }
$$

فقرات مقياس مجال اوعي مرتبة تنازليا حسب أوساطها المرجحة

\begin{tabular}{|c|c|c|c|c|c|c|}
\hline الوسط & \multicolumn{4}{|c|}{ التكرار ات حسب البدائل } & \multirow{2}{*}{ رقة } & \multirow{2}{*}{ الرتبة } \\
\hline & 1 & r & $\mu$ & $\varepsilon$ & & \\
\hline$r, \Lambda$ & $\varepsilon$ & $\varepsilon$ & 7. & $7 \varepsilon$ & 9 & 1 \\
\hline$r, v$ & - & $\varepsilon$. & rq & rr & 1. & r \\
\hline$r, \varepsilon$ & Ir & 17 & rr & ry & 1 & $\mu$ \\
\hline$r, r$ & $\varepsilon$ & $\varepsilon$. & $r \varepsilon$ & rr & r & $\varepsilon$ \\
\hline$r, r$ & Ir & r. & $r r$ & $r \varepsilon$ & V & ○ \\
\hline $1, \vee 0$ & $r$. & 1. & r. & $r$. & 7 & 7 \\
\hline 1,70 & $r$. & $\varepsilon$ & $\mu$ & ir & $\Lambda$ & V \\
\hline 1,00 & rq & 1. & 10 & $\Lambda$ & $r$ & $\Lambda$ \\
\hline 1,20 & ro & $r \varepsilon$ & 9 & - & $\varepsilon$ & 9 \\
\hline $1, Y 0$ & r. & $r$. & - & - & ○ & 1. \\
\hline
\end{tabular}

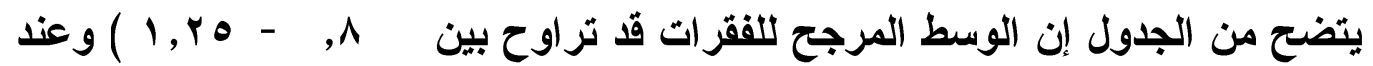

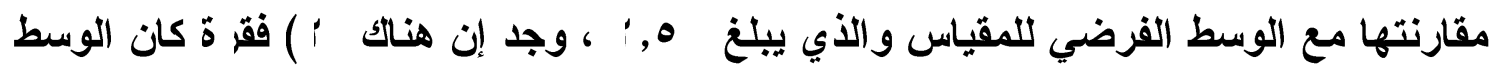

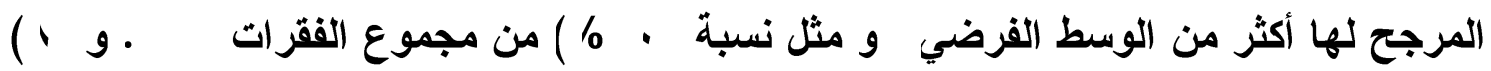

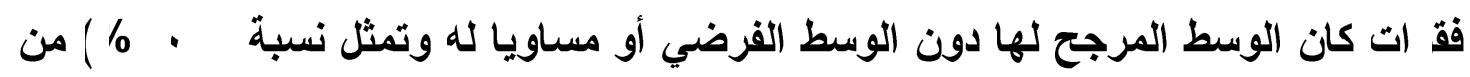

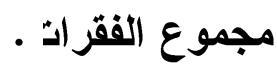




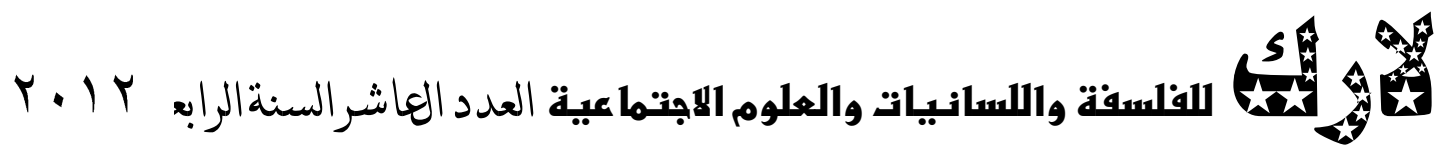

- فقرات مقياس مجال الاستر اتيجية المعرفيً: : تضمن 1 ) فقرات رتبت تنازليا كما في

جدول i

$$
\text { جدول i (i) }
$$

فقرات مقياس مجال الاستر اتيّم ية المعرفية مرتبة تنازليا حسب أوساطها المرجحة

\begin{tabular}{|c|c|c|c|c|c|c|}
\hline اللوسط & \multicolumn{4}{|c|}{ التكرارات حسب البدائل } & \multirow{2}{*}{ رقم } & \multirow{2}{*}{ الرتبة } \\
\hline & 1 & $r$ & $r$ & $\varepsilon$ & & \\
\hline$r, \Lambda$ & $\varepsilon$ & $r \varepsilon$ & ry & $\varepsilon \wedge$ & 11 & 11 \\
\hline Y.VO & $\varepsilon$ & 17 & ry & $7 \varepsilon$ & 11 & Ir \\
\hline$r, V$ & $\varepsilon$ & 17 & VY & 17 & 19 & 14 \\
\hline$r, V$ & - & $\varepsilon$. & ry & rr & Ir & $1 \varepsilon$ \\
\hline 1,90 & Ir & q & $r$. & - & 10 & 10 \\
\hline $1,9 r$ & YI & rr & $r \varepsilon$ & - & ir & 17 \\
\hline $1,7 \mathrm{~V}$ & rA & $1 \varepsilon$ & 10 & - & IV & $1 V$ \\
\hline r & rV & Y & - & - & 17 & 11 \\
\hline $1,1 \mathrm{~V}$ & 18 & $r$. & 7 & $\varepsilon$ & $1 \varepsilon$ & 19 \\
\hline
\end{tabular}

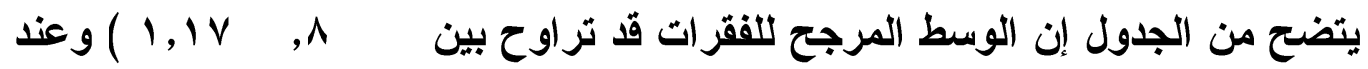

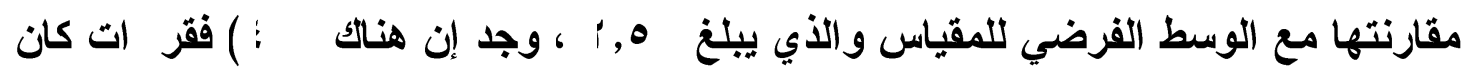

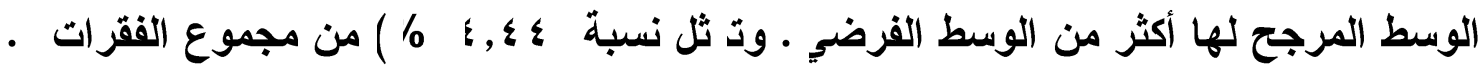

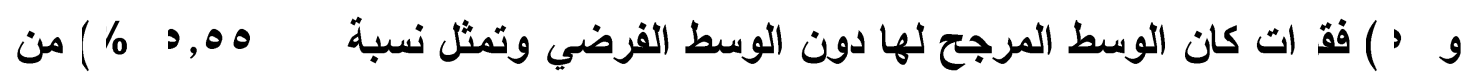

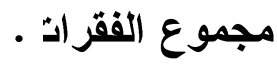




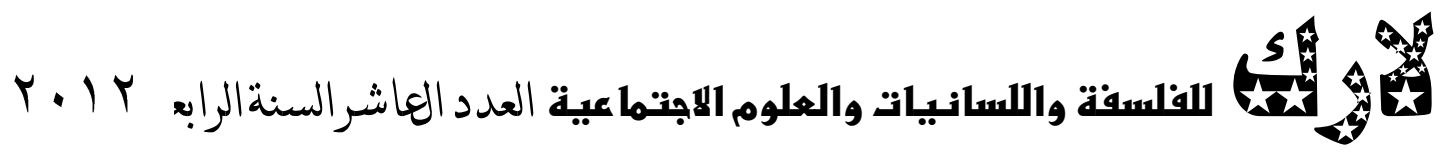

- فقرات مقياس مجال التخطيد : تضمن r ) فقرة رتبت تنازليا كما في جدول .

$$
\text { جدول }
$$

فقرات مقياس مجال التخطيط مرتبة تنازليا حسب أوسـاطها المرجحة

\begin{tabular}{|c|c|c|c|c|c|c|}
\hline الوسط & \multicolumn{4}{|c|}{ التكر ارات حسب البدائل } & \multirow{2}{*}{ رقم } & \multirow{2}{*}{ الرتبة } \\
\hline & 1 & $r$ & $\mu$ & $\varepsilon$ & & \\
\hline$r, 7$ & $\Lambda$ & 17 & $\varepsilon \wedge$ & $r r$ & $r \varepsilon$ & $r$. \\
\hline$r, 0$ & Ir & 17 & $r \varepsilon$ & $\varepsilon \wedge$ & $r$. & YI \\
\hline$r, \xi$ & $\Lambda$ & rr & $r \varepsilon$ & $r r$ & $r V$ & rr \\
\hline$r, 1$ & 17 & $r \varepsilon$ & Ir & $r r$ & $r \wedge$ & $r r$ \\
\hline $1,9 \mathrm{~V}$ & $1 \%$ & r. & ry & - & r & $r \varepsilon$ \\
\hline 1,90 & 17 & $r \varepsilon$ & $r$. & $\Lambda$ & rr & ro \\
\hline $1,9 r$ & $r r$ & 17 & 10 & $r \varepsilon$ & ro & Y \\
\hline $1, \wedge r$ & $r \varepsilon$ & $r$. & 10 & $\varepsilon$ & $r r$ & YV \\
\hline $1, \wedge$ & rA & $\Lambda$ & ry & - & YI & rA \\
\hline 1,1 & $1 \varepsilon$ & $\varepsilon$. & 11 & - & rq & rq \\
\hline $1,7 r$ & 10 & 0 . & - & - & rq & r. \\
\hline 1,00 & $r$. & $\mathrm{r} \wedge$ & - & $\varepsilon$ & $r$. & r \\
\hline
\end{tabular}

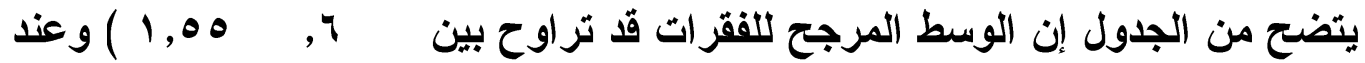

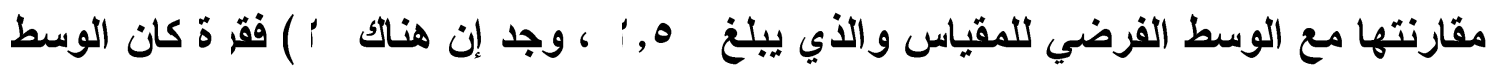

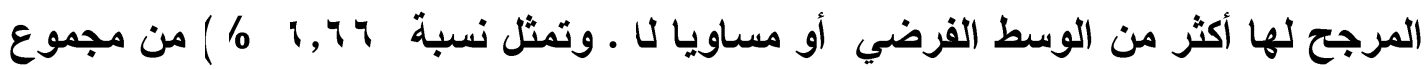

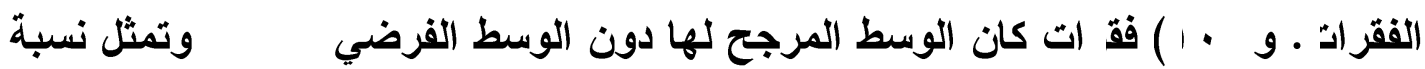

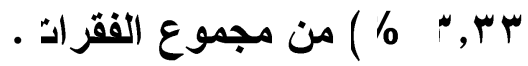




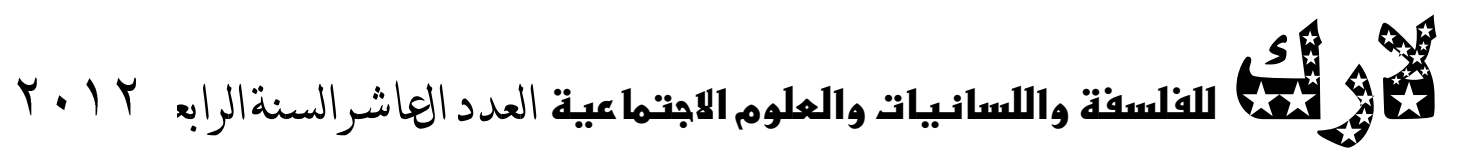

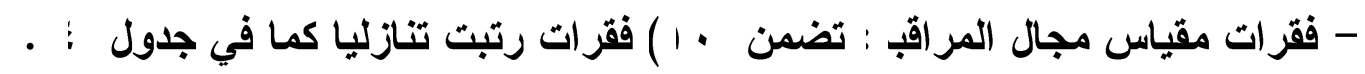

$$
\text { جدول: (: (2) }
$$

فقر ات مقياس مجال التخطيط مرتبة تنازليا حسب أوساطها المرجحة

\begin{tabular}{|c|c|c|c|c|c|c|}
\hline الوسط & \multicolumn{4}{|c|}{ التكرارات حسب البدائل } & \multirow{2}{*}{ رقم } & \multirow{2}{*}{ الرثبة } \\
\hline & 1 & $r$ & $r$ & $\varepsilon$ & & \\
\hline$r, V$ & $\Lambda$ & 17 & rq & $\varepsilon \Lambda$ & rA & rr \\
\hline$r, 0$ & $\Lambda$ & 17 & 7. & 17 & rr & $r \mu$ \\
\hline$r, \varepsilon$ & $\varepsilon$ & $\varepsilon$. & rq & 17 & rq & r \\
\hline$r, V$ & 18 & $r r$ & - & $\varepsilon \wedge$ & $\{1$ & Q \\
\hline$r, 1$ & $\Lambda$ & 17 & rq & $r \varepsilon$ & r & ד \\
\hline $1, \wedge 0$ & $1 r$ & $\varepsilon \varepsilon$ & 11 & - & $\varepsilon$. & rv \\
\hline $1, \Lambda$ & 11 & $r \varepsilon$ & $\mu$. & - & rq & $\mu \wedge$ \\
\hline $1,7 \mathrm{~V}$ & 11 & $r \varepsilon$ & 10 & - & $r v$ & rq \\
\hline 1,70 & $r r$ & $r \varepsilon$ & - & - & $r \varepsilon$ & $\varepsilon$. \\
\hline $1,0 \mathrm{~V}$ & 19 & $\varepsilon$. & - & $\varepsilon$ & ro & $\varepsilon 1$ \\
\hline
\end{tabular}

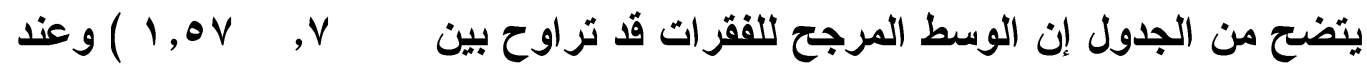

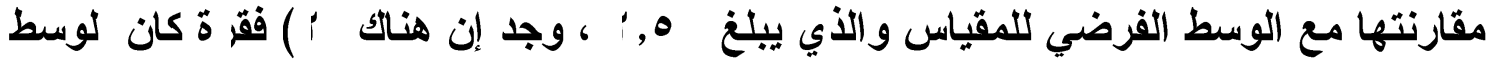

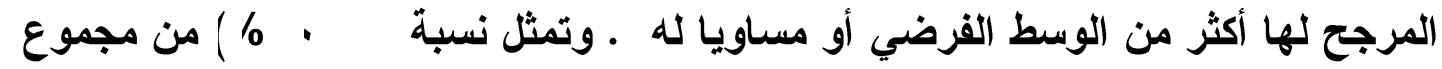

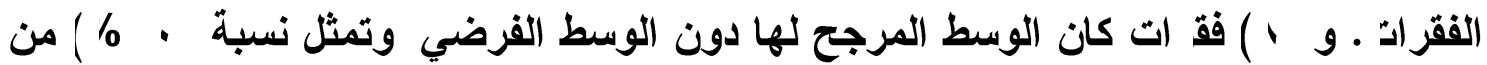
مجموع الفقر اد . 


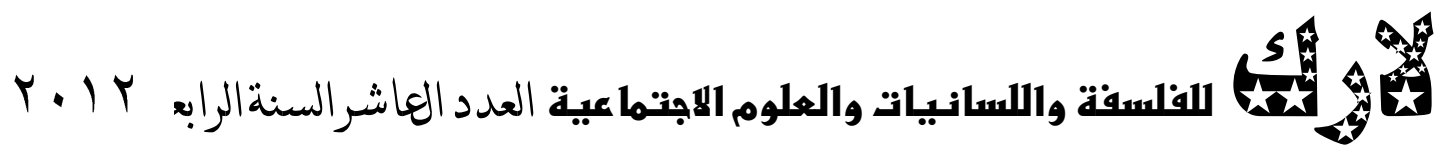

- فقرات مقياس مجال المراجعة والتقوي : تضمن ب ا ) فقرة رتبت تنازليا كما في جدول

$$
\text { جدول ( ) }
$$

فقرات مقياس مجال المر اجعة والتقويم مرتبة تنازليا حسب أوساطها المرجحة

\begin{tabular}{|c|c|c|c|c|c|c|}
\hline اللوسط & \multicolumn{4}{|c|}{ التكرارات حسب البدائل } & \multirow{2}{*}{ رقم } & \multirow{2}{*}{ الرتبة } \\
\hline & 1 & $r$ & $r$ & $\varepsilon$ & & \\
\hline$\mu$ & - & 17 & Vr & $r r$ & $\varepsilon \wedge$ & $\varepsilon Y$ \\
\hline$r, q$ & - & $\wedge$ & 7. & $\varepsilon \wedge$ & $\varepsilon q$ & $\varepsilon r$ \\
\hline$r, 0$ & $\Lambda$ & 17 & 7. & 17 & $\varepsilon V$ & $\varepsilon \varepsilon$ \\
\hline$r, \xi$ & $\varepsilon$ & $\varepsilon$. & r & 17 & ๑. & $\varepsilon 0$ \\
\hline $1, \Lambda$ & $r$. & 17 & 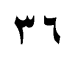 & - & or & $\varepsilon 7$ \\
\hline $1, \vee 0$ & 19 & rq & YI & $\varepsilon$ & $\varepsilon \varepsilon$ & $\varepsilon V$ \\
\hline $1,7 r$ & $r$ & $r$ & 10 & - & $\varepsilon 0$ & $\varepsilon \wedge$ \\
\hline $1,0 r$ & $r \varepsilon$ & rr & 10 & - & $\varepsilon r$ & $\varepsilon 9$ \\
\hline $1, r r$ & rq & $r$. & $r$ & $\varepsilon$ & $\varepsilon r$ & •. \\
\hline $1, \varepsilon$ & r & $\varepsilon$ & $r_{1}$ & - & or & 01 \\
\hline $1, \mu_{0}$ & r & - & Y & - & 01 & Or \\
\hline $1, r r$ & $r q$ & $r$. & $r$ & $\varepsilon$ & $\varepsilon r$ & $\Delta r$ \\
\hline $1, r o$ & r. & $r$. & - & - & $0\}$ & $0 \varepsilon$ \\
\hline
\end{tabular}

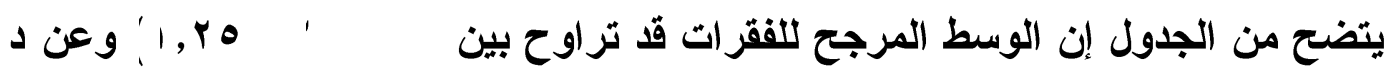

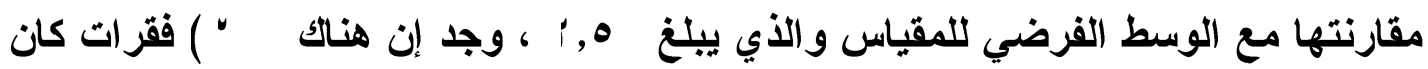




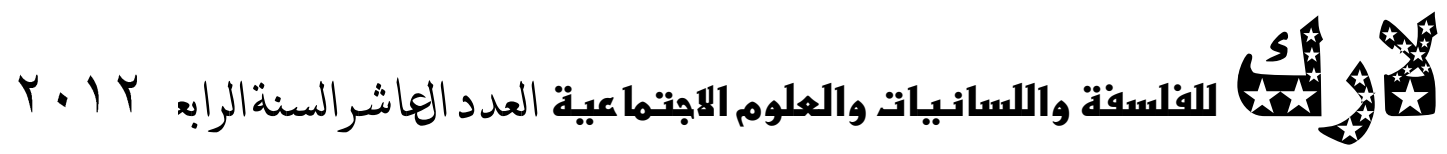

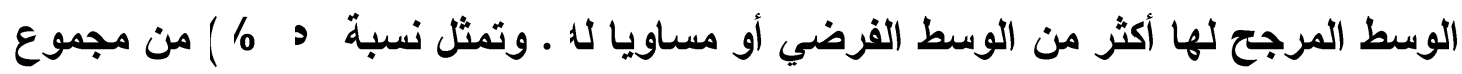

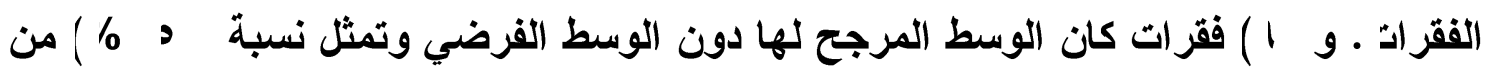

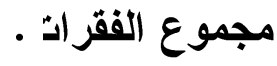

يتبين من النتائج أعلاه ضعف امتلاك الطلاب لمهارات ما وراء المعرفة وعدم قدرتهم

على تجاوز الوسط الفرضي يعود لعدة أسباب قد يكون من أهمها ضعف الخبرات التراكمية

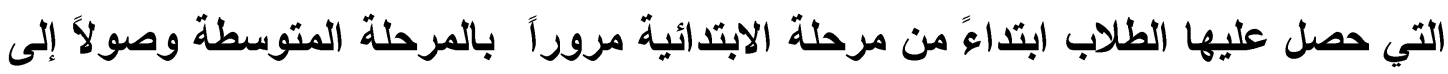

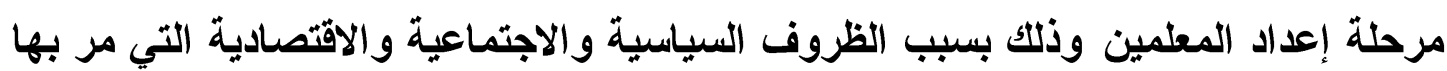
الثعب العراقي فضلاً عن ضعف الخبرات المعرفية والمهارية التي يتلقاها الطلبة في مرحلة المعهد التي لم تكن كافية، إذ لم تنمي القدرات على التفكير بصورة جيدذ ـ وأيضاً قد يعود السبب إلى أن هذا النوع من المقاييس غير مألوف لاى الطلاب مما سبب بعض الارتباك

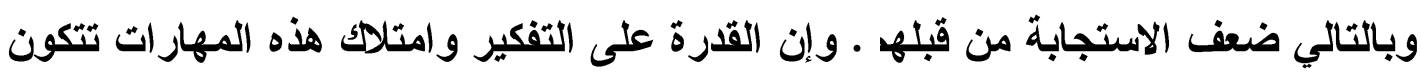

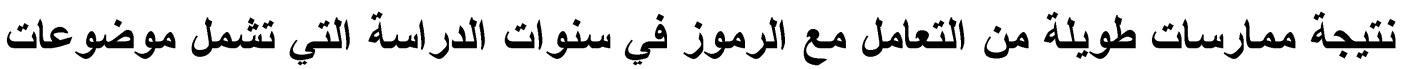

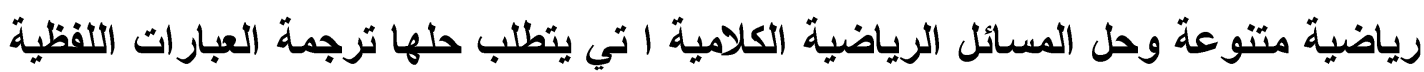
إلى رموز، وإن هناك مواد دراسية أخرى تسهم في قرة الطلبة على التفكير عن طريق تداخل

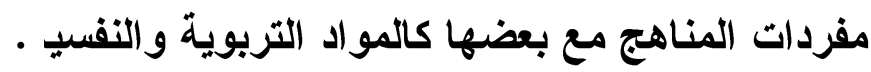

\section{التوصيات:}

$$
\text { في ضوء هذه الاراسة يوصي الباد ان بعدة توصيات وهـ :- }
$$

ا رفع كفاءة مدرسي العلوم أ تربوية والنفسية في معاهد إعداد المعلمين عن طريق عقد دورات تلريبية متخصصة لهم لغرض رفع مهار ات التفكير لاى الطلب .

r اس عمار الأسئلة المثيرة للتفكير ولا سيما مهارة التفكير العليا والابتعاد عن أسئلة الحفظ و الثنكر

ب تعريض الطلبة إلى مواقف حياتية وتطبيقية متنوعة تطلب منهم اللجوء إلى است عمال

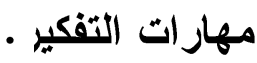
ع استخدام التقويم بهدف التشخيص وليس إصدار حكم نهائح . 


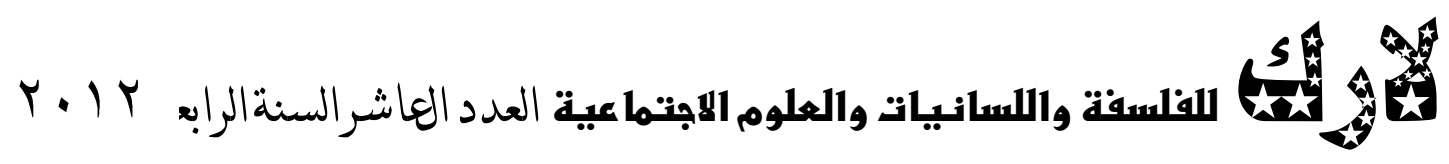

المقترحاذ:

في ضوء هذه الار اسة وضع الباد ان عدة مقترحات مستقبلية وهر :-

ا إجراء دراسات مماثلة لهذه الاراسة وعلى عينات من الطلبة لمر احل دراسية أخرى كطلبة المتوسطة و الإعدادي .

r إجراء در اسات تحليلية لمحتوى مناهج معاهد إعداد المعلمين لتحديد مهارات التفكير وإعادة النظر بالمحتوى المعرفي ككا .

r القيام بلراسات تجريبية للكشف عن أفضل الطرائق التي تساعد على تنمية مهارات التفكير بشكل عام والعليا بشكل خاص .

\section{خ المصادر العريبة}

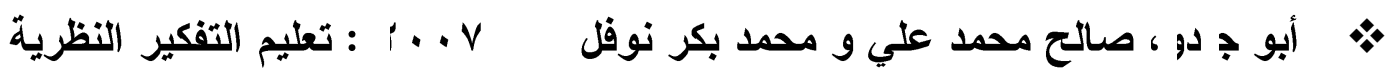

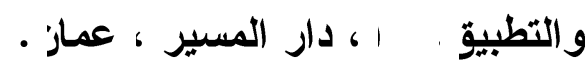

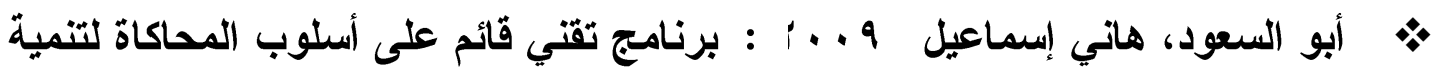

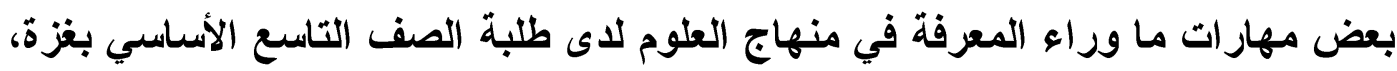
رس لة ماجستير غير منشور ، كلية التربية، الجامعة الإسلامية، غزة فئة

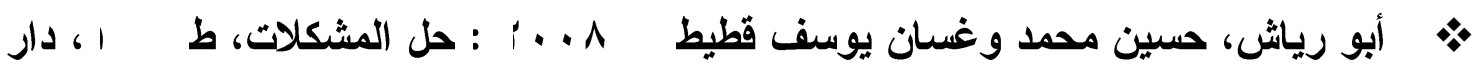

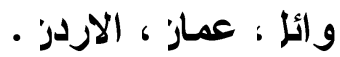

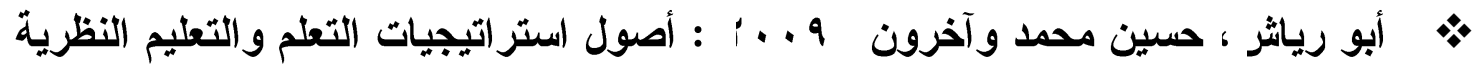

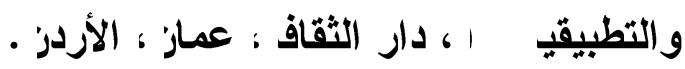

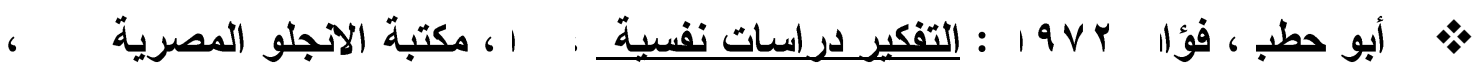
القاهر -

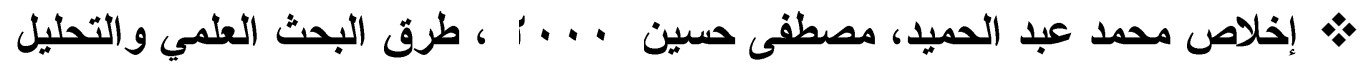
الاحصائي في المجالات التربوية والنفسية والرياضية، مركز الكتاب، القاهر •

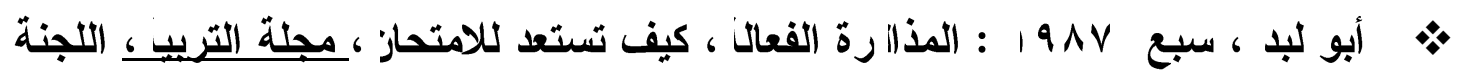
الوطنية للتربية والثقافة والعلو ، قطر . 


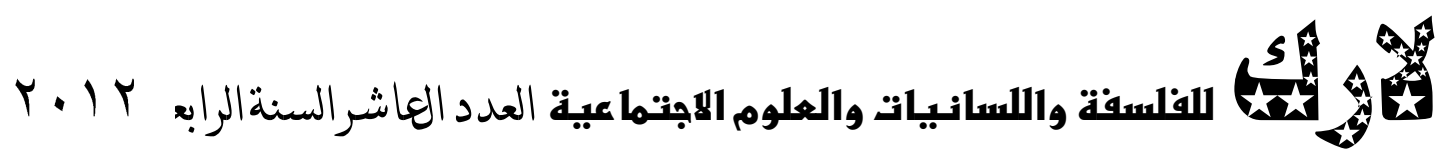

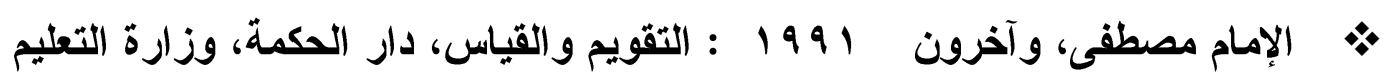
العالي والبحث العلمي، بغدا .

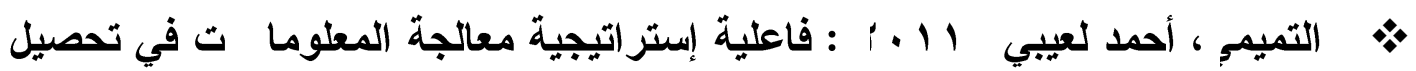

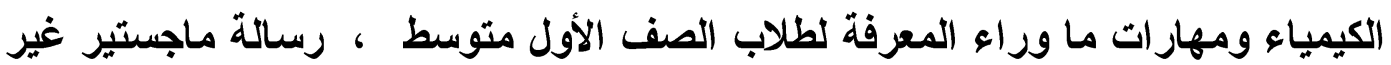

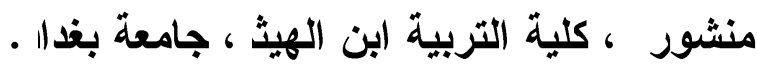

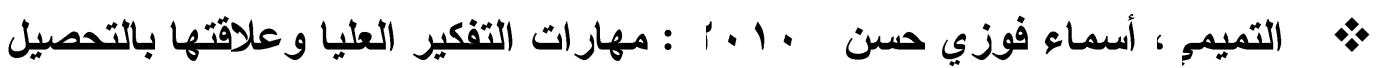
الرياضي لاى طلبة معاهد إعداد المعلمين ، رسالة ماجد تيرغير منشور ، ، كلية التربية ابن

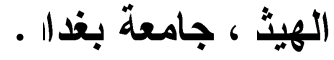

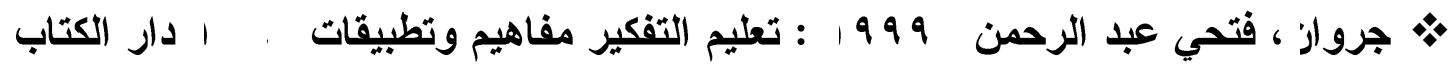
الجامعح : عماز .

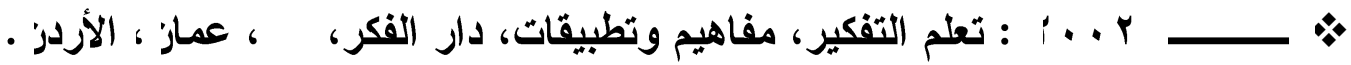

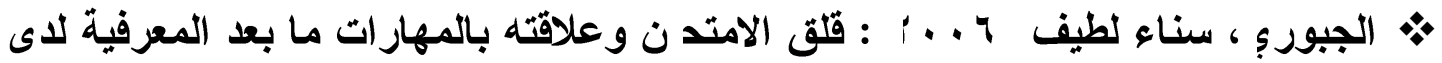
طلبة ثانويات المتميزيز ، أطروحة دكتورا ، الجامعة المستنصري .

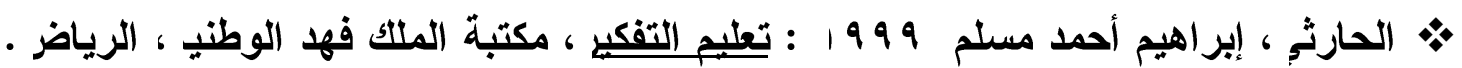

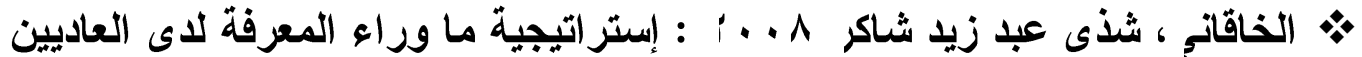
و المتميزين والموهوبين من طلبة المرحلة المتوسطن رسالة ماجستير غير منشورة ، كلية

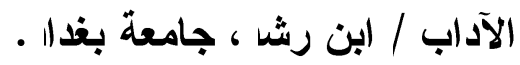

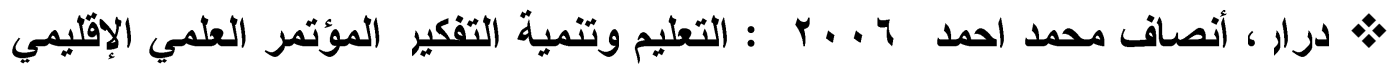
للموهبذ - تربية من اجل المستقبل " مؤسسة الملك عبد العزيز لرعاية ال وهوبين ، المملكة العزبية السعوديد البية

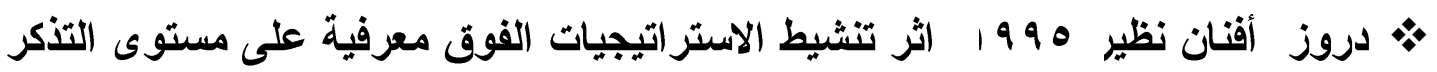

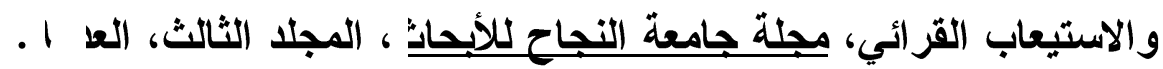

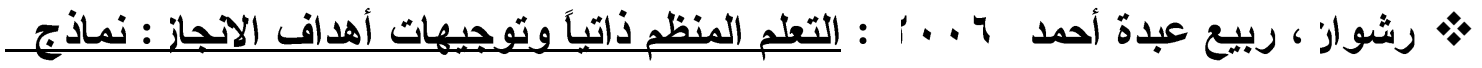

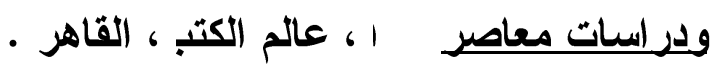




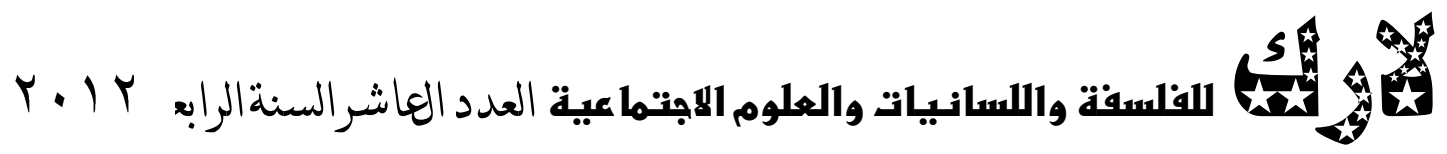

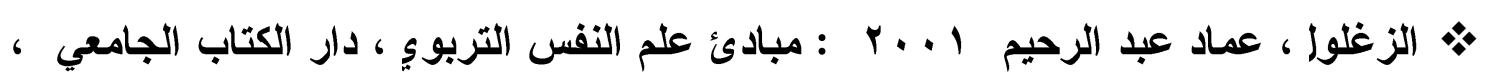

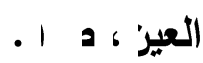

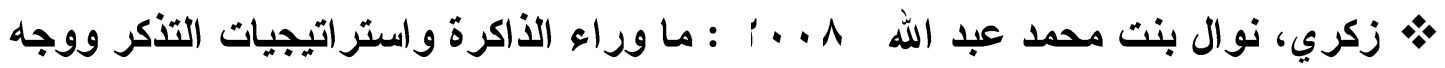

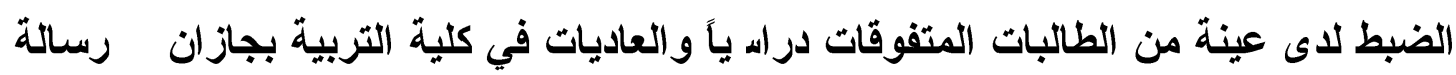
ماجستير غير منشور ، كلية التربية، جامعة أم القرى، المملكة العربية السعوديد .

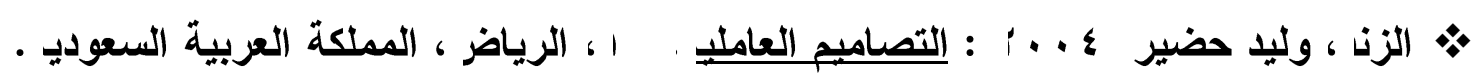
• الزيات فتحي مصطفى 1999 1 : سيكولوجيا التعلم بين التطو ر ألارتباطي والتطور

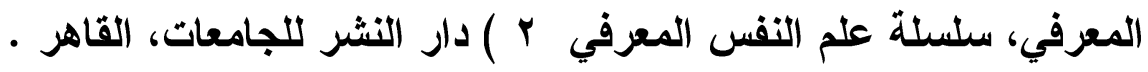

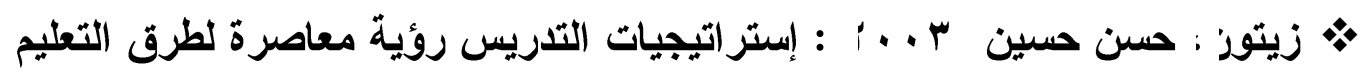

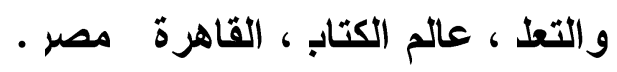

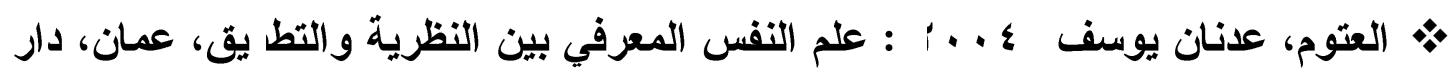
المسيرة للنشر والتوزيع، الأردز .

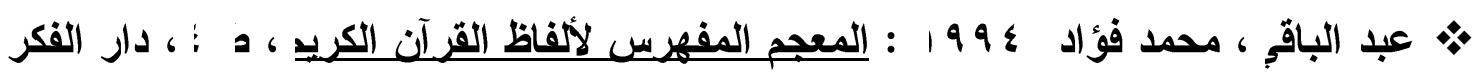

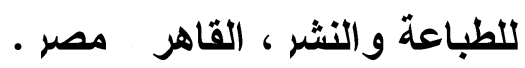

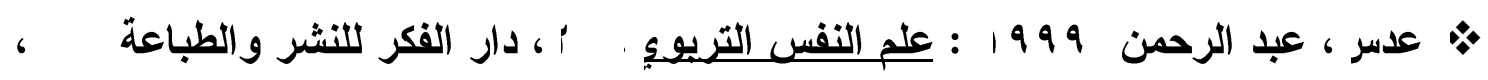
عماز ، الاردرز •

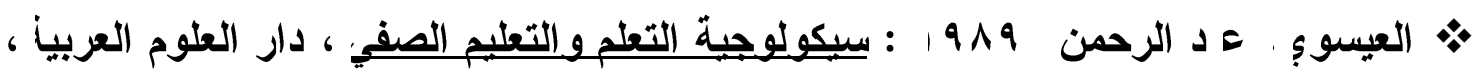

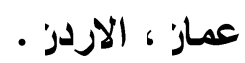

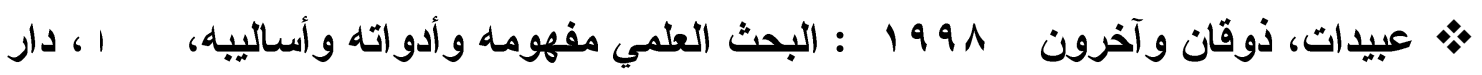

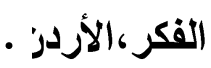

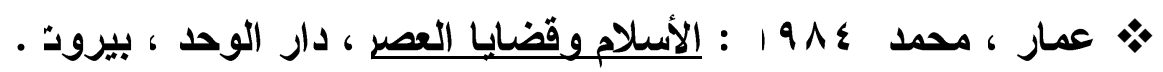
* عبد السلام، مصطفى عـد السلا 7 . . 1 : تدريس العلوم ومتطلبات العصر، ط ، مطابع إياك كوبي سنتر، المنصورة، مصر • 


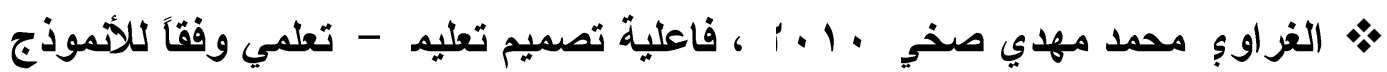
المعرفي في تنمية مهار ات التفكير العليا وتعديل التصور ات الخاطئة والتحصيل التوعي في مادة الفيزياء لاى طلبة كلية التربية الأساسية ، أطروحة دكتور اه غير منشورن ، كلية التربية

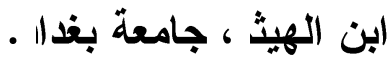

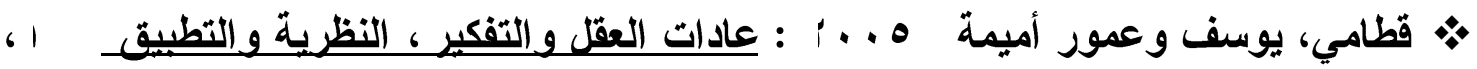

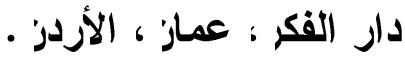

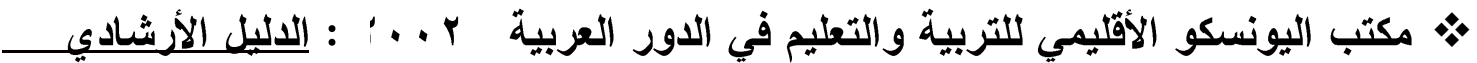
لأدخال وتطوير التريبة التكنوليوية في التعلم العا، ، ا، مكتب اليونسكو الأقليمج ، بيرود . المصادر الاجنبي : n

* Anastasi, Susan urpina ,(1997): Psychological testing, by prentice Hall , Inc. New Gersey.

* Barell , J. (1991). Creating our pathways: Teaching students to think and become self - directed. In N. Colangelo \& G. A. Davis (Eds.), Handbook of gifted education (PP.256-270). Needham Heights, MA:Allyn and Bacon.

* Costa, A. L. (2000): Teaching for Intelligence Recognizing and encouraging skillful Thinking and behavior

* moKouider and Reichard, (2002). Metacognitive Training Within a Problem solving Based logo Environment. British Journal of Educational Psychology. Vol. 67. (PP:425-445).

* Romainville, M. (1994). Awareness of cognition strategies Relation ship between university studnt's. Metacognition and their performance studies in Higher Education, Vol (19). No (2), PP:359-366.

* Marzano, Robert(1992): Dimensions of Thinking. Alexandria-V-AAssociation for Supervision and Curriculum Development 
* Barell , J. (1991). Creating our pathways: Teaching students to think and become self - directed. In N. Colangelo \& G. A. Davis (Eds.), Handbook of gifted education (PP.256-270). Needham Heights, MA:Allyn and Bacon.

* Lipman, M. (1991). Sterngthening reasoning and Judgment through Philosophy. Ins. Maclure \& P. Davis (Eds.), Learning tothink, thinking to learn. (pp. 103 - 113). Ox ford, UK:Pergamon ptess plc.

* Paris S. G. \& Winograd, P.W (1990). How Metacgnition can promote a cademic learning and instruction, In B. J. Jones \& Idol (Eds.), Dimensions of thinking and cognitive instruction, (PP 15-51) Hillsdale N J:Lawrence Eribaum Associates.

* Sternberg, R. J. \& Caruso,D.R (1985). Practical Models of knowing, In E. Eisner and K. J. Renage (Eds) Learning and Teaching: The Way of know , Chicago: University of Chicago press.

* Time, Robert, (1988): psychology and adult learning London rout ledge.

* Your, L. D. 7 Craug, M.(1992). Middle school students Metacognitve knowledge About Science kiading and science Text: objective Assessment, Validation, and Results. A Dialogue search FromEkic Data base.

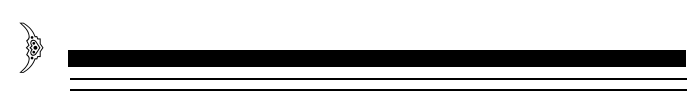




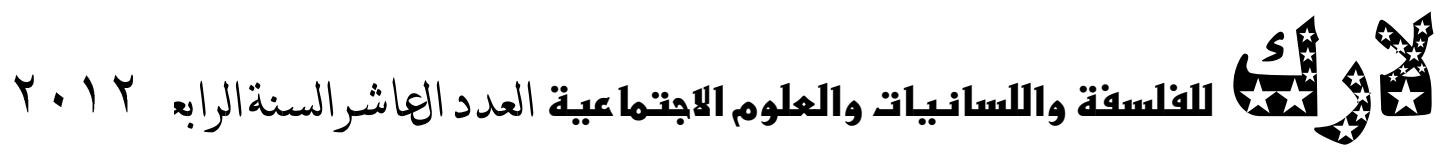

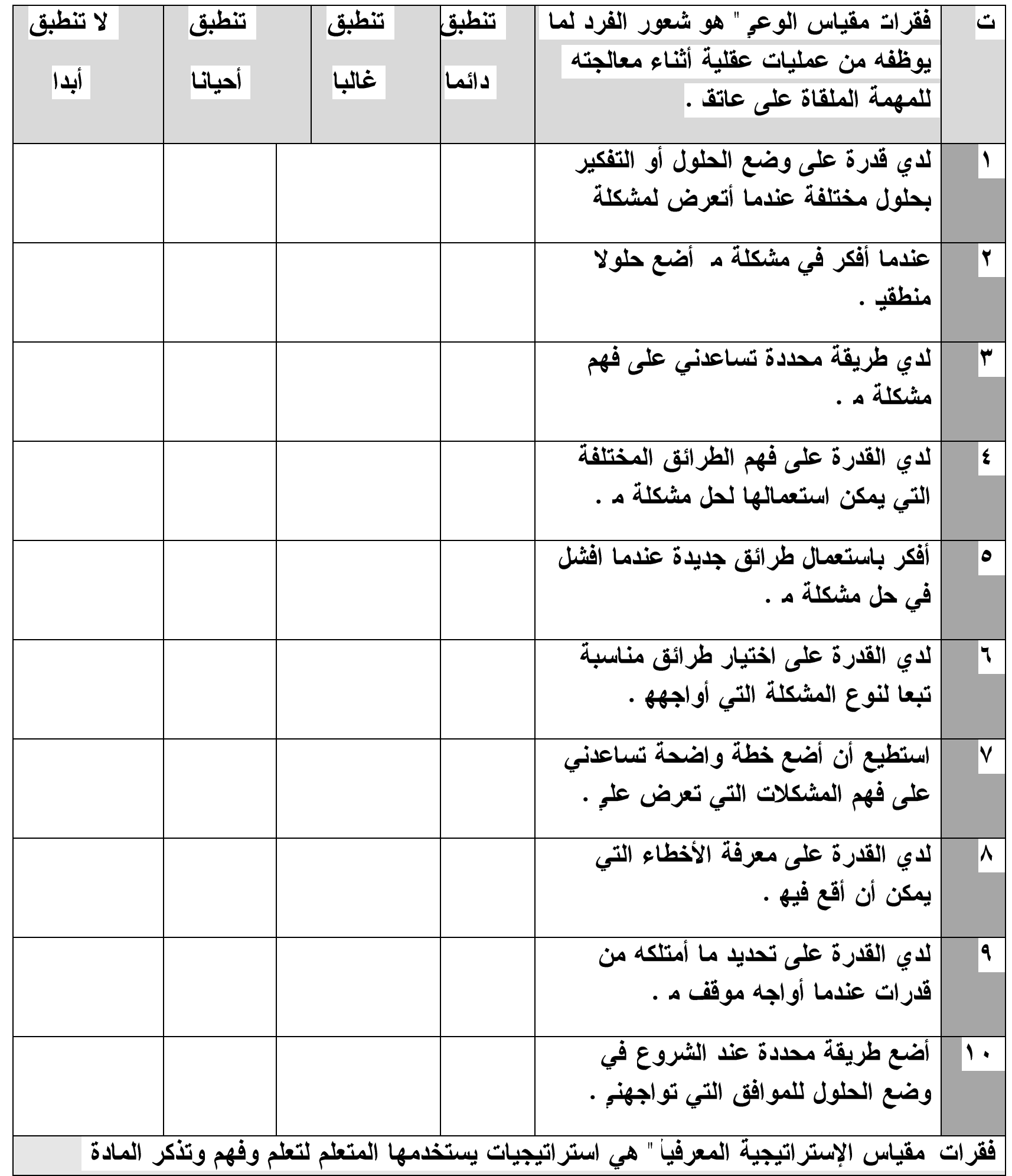




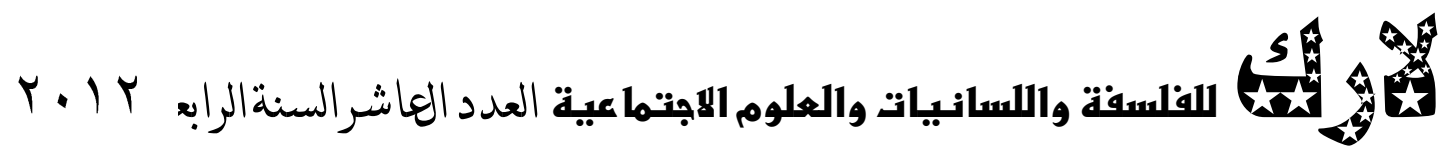

الدراسية ومن أمثلتها الاسميع الأهني والاسترجاع والتفصيل والتنظيم والترميز .

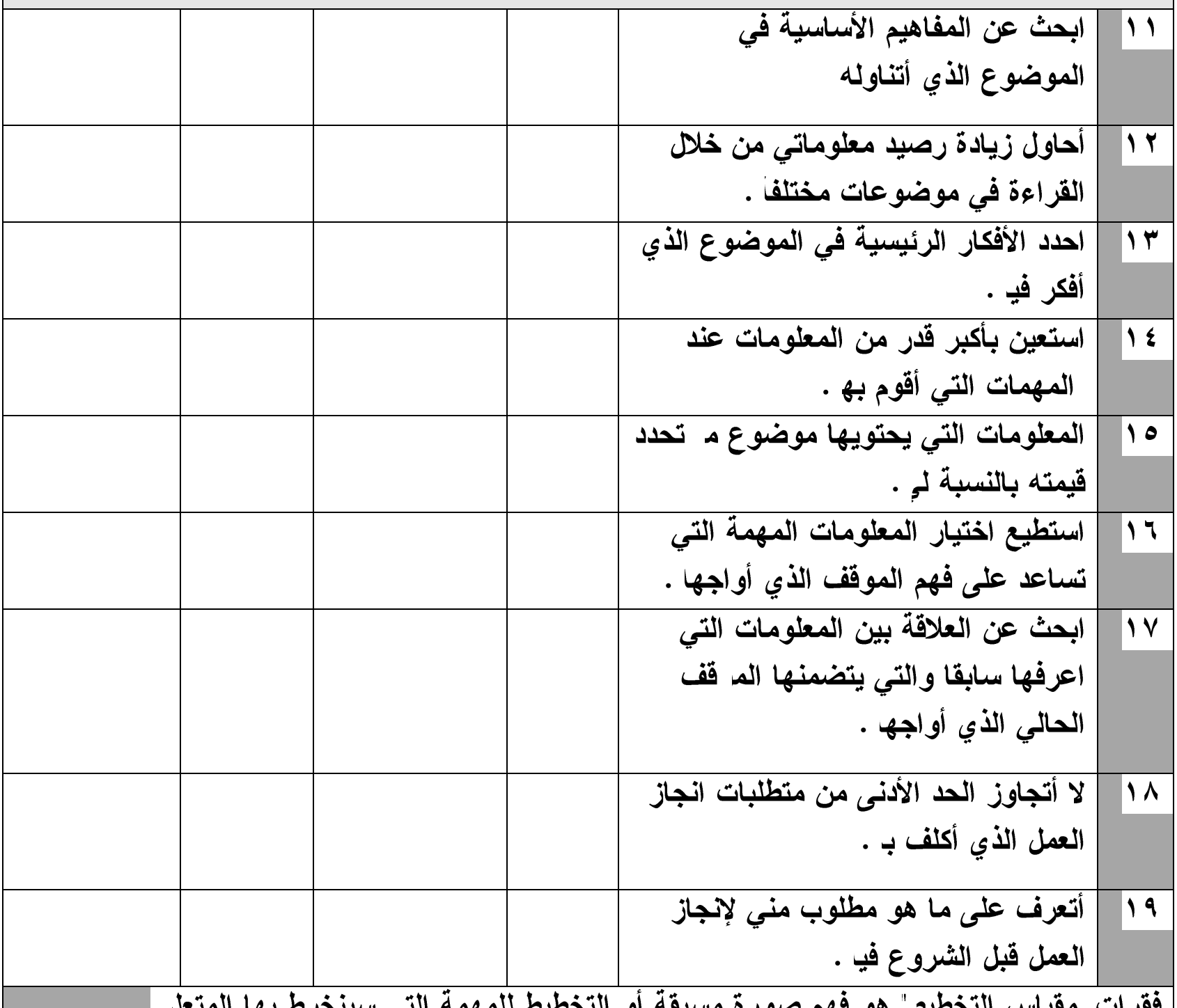

فقرات مقياس التخطيد" هو فهم صورة مسبقة أو التخطيط للمهمة التي سينخرط بها المتعل .

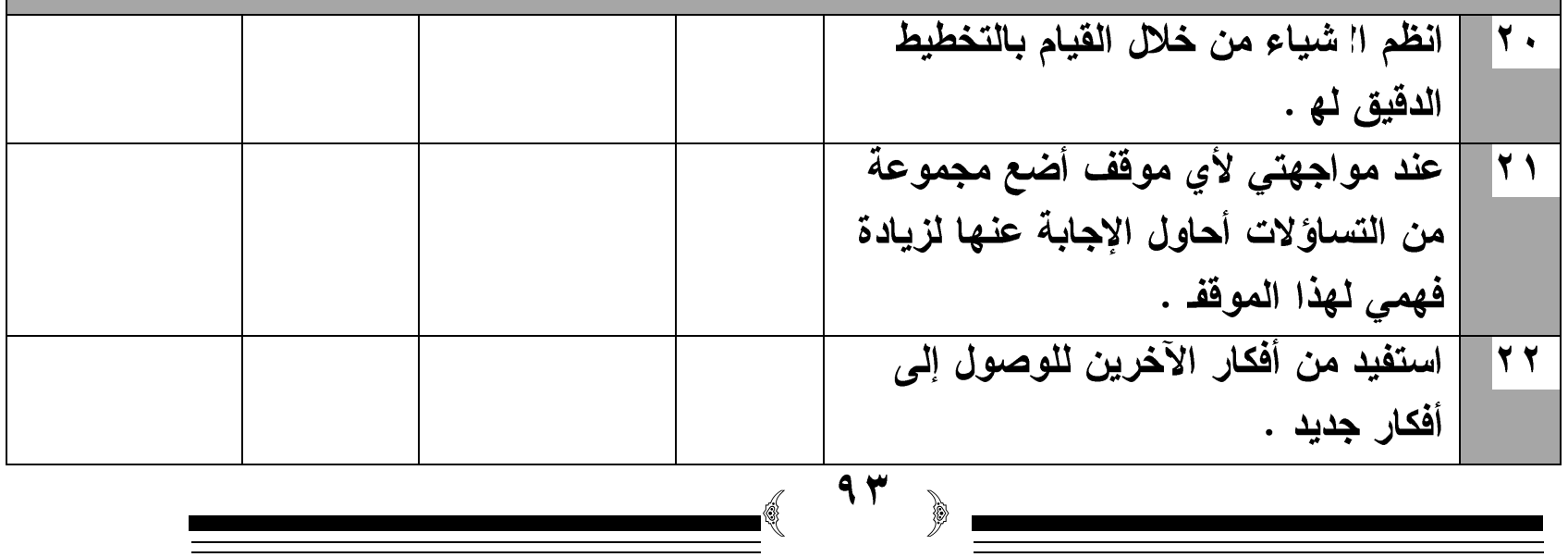




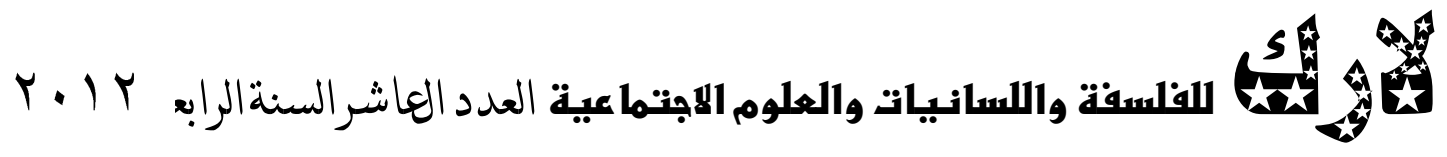

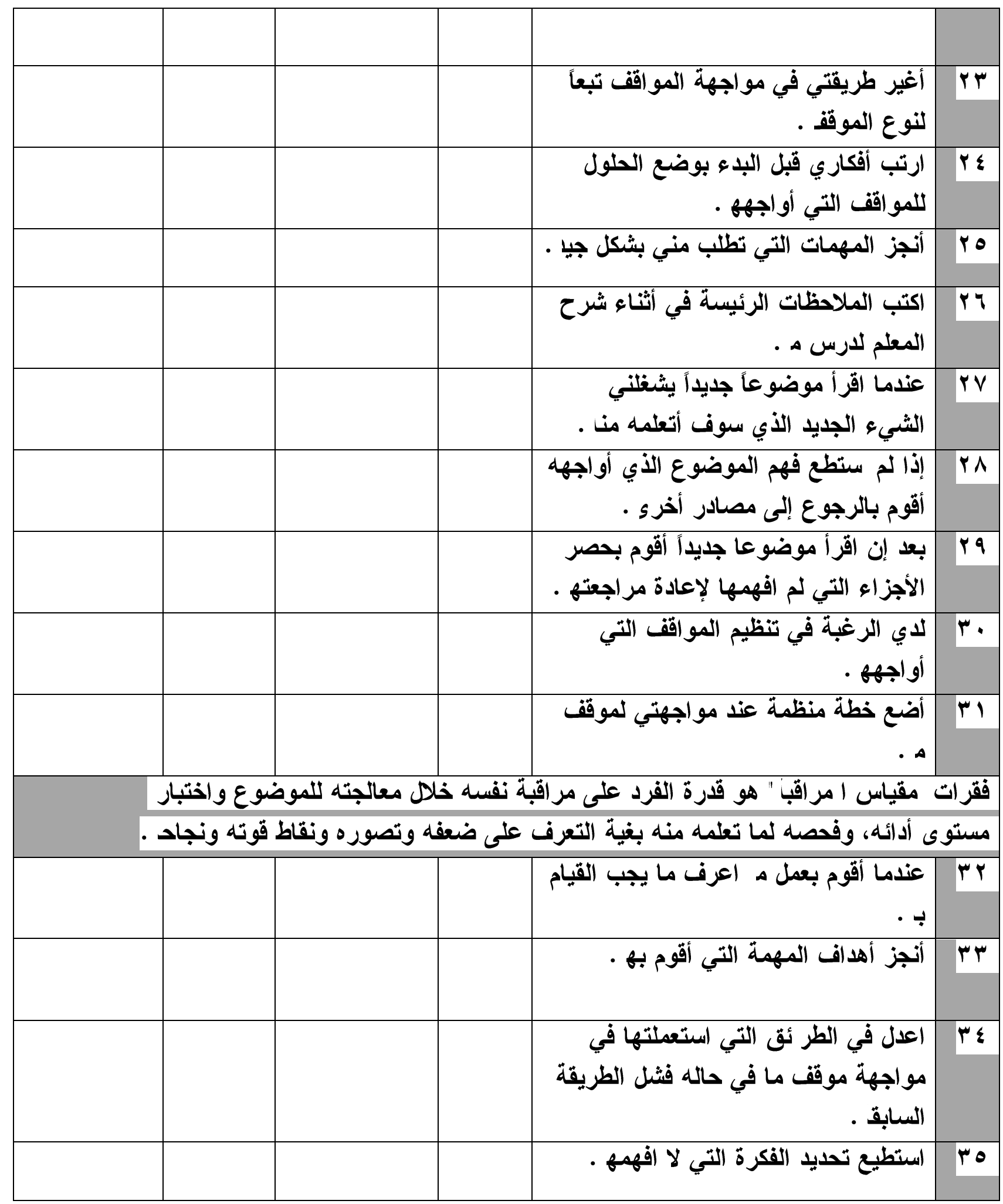




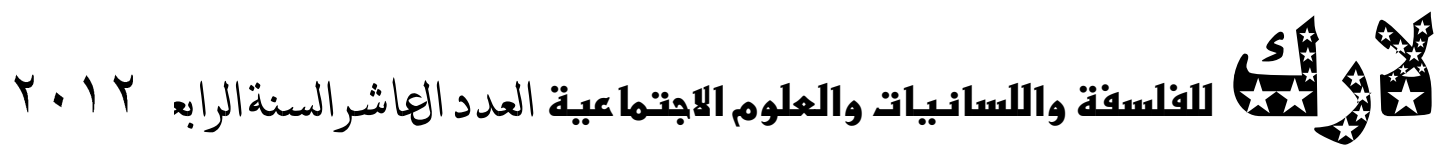

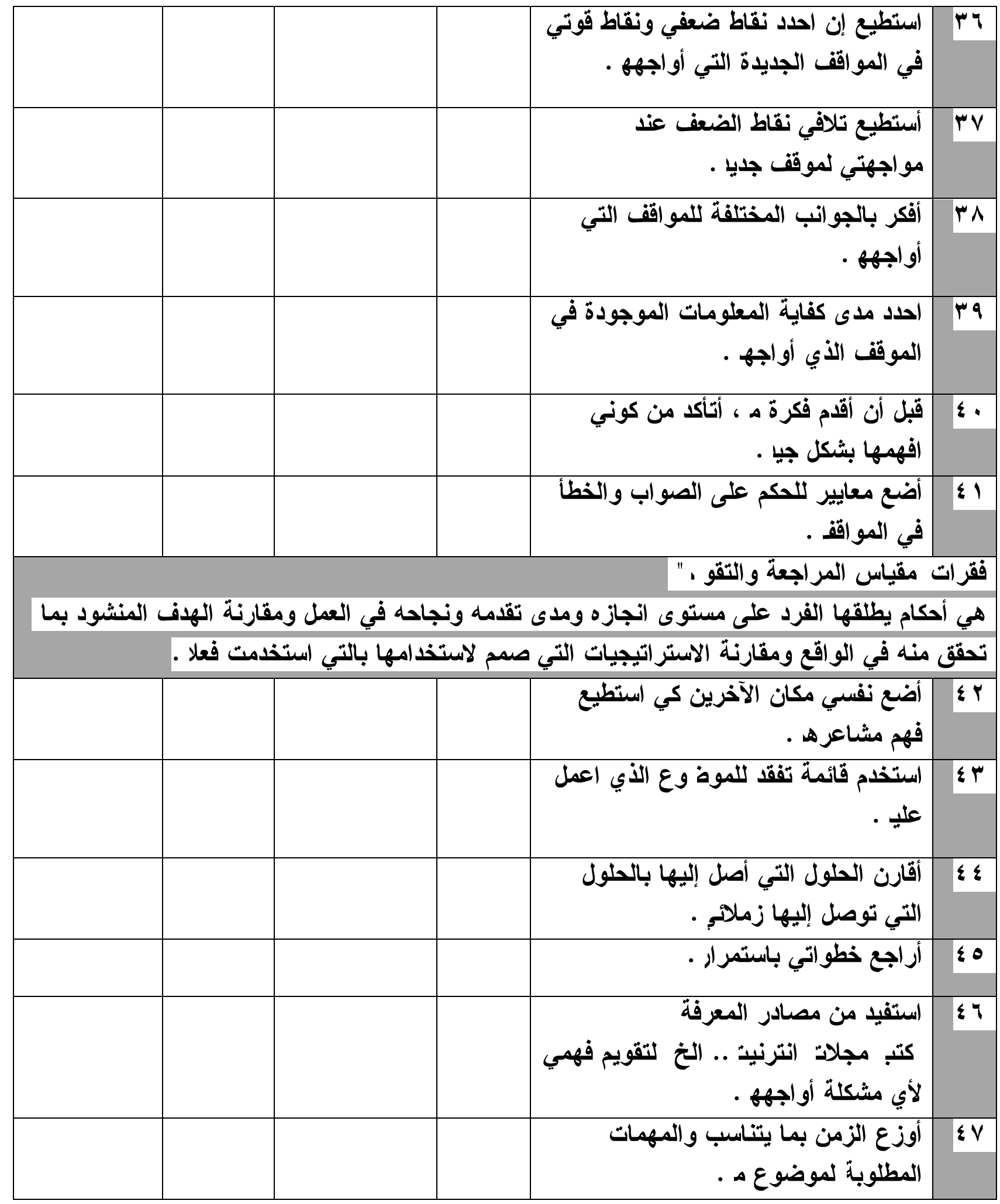




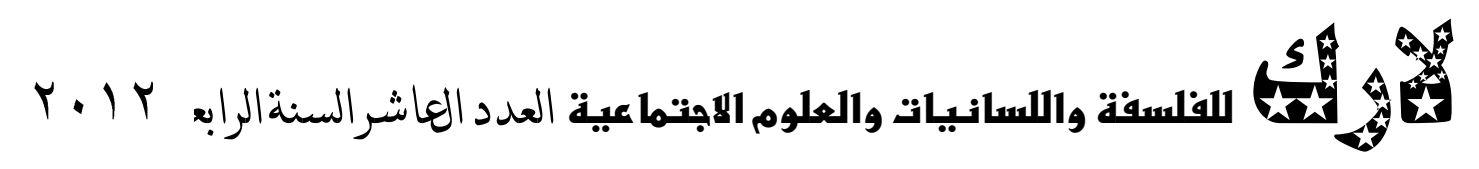

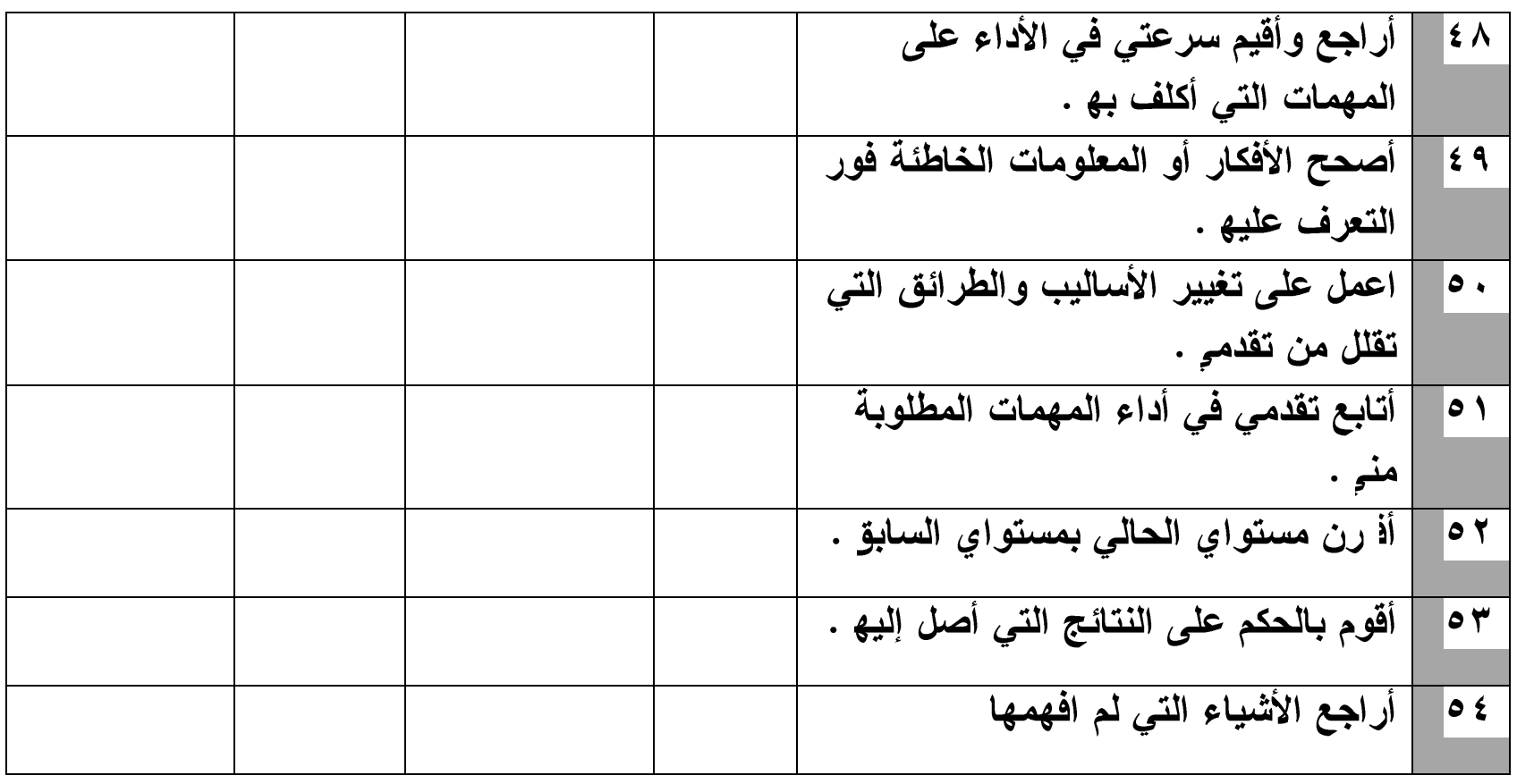




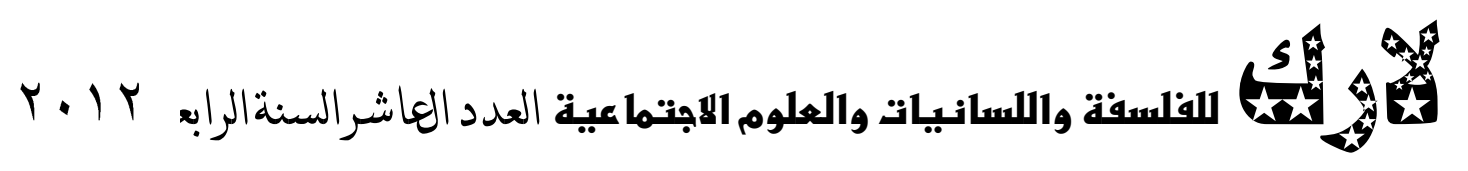

\section{ملحق 1 )}

مقياس مهار ات ما وراء المعرفة بصورته التهائية

عزيزي الطالب .

يعرض عليك فيما يلي عدد من العبارات التي تصف وعي الفرد ومعرفت ه وفهمه و إدراكه لما

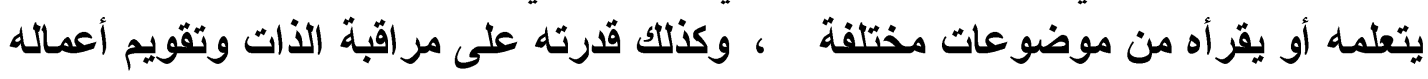

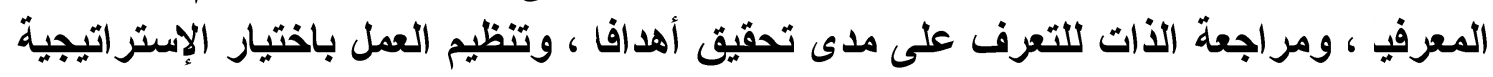

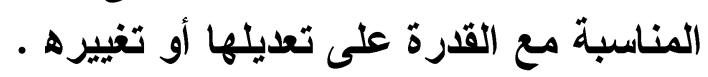

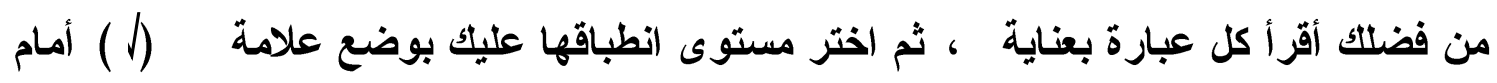

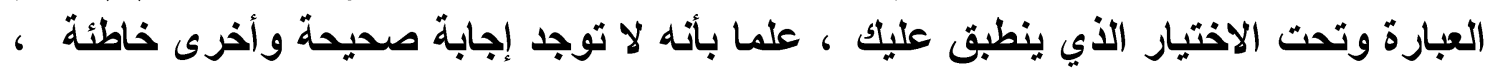

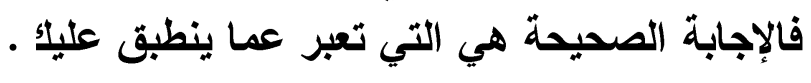

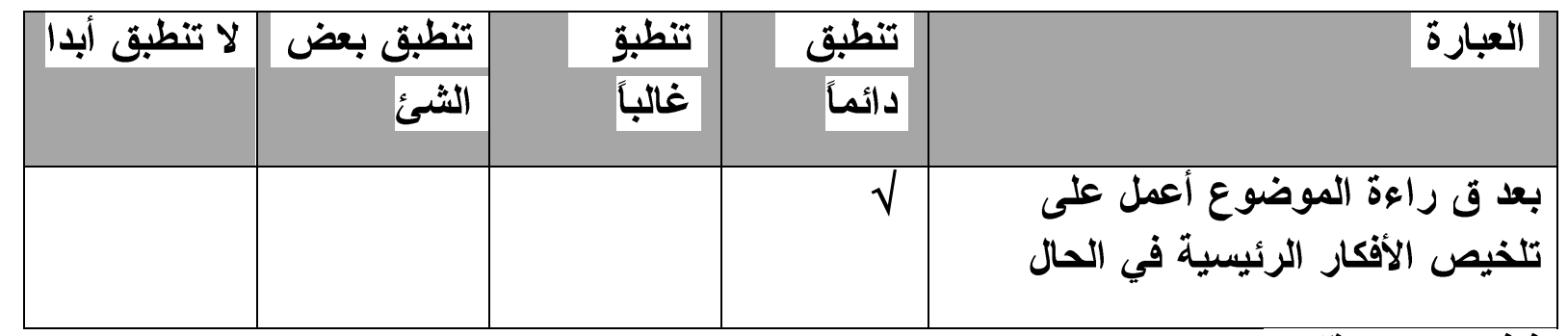

فإِذا كان الموقة :

يحدث في جميع الأحيان ضع العلامة أمام العبارة تحث تنطبق دائم و إذا كاتت تحدث في معظم

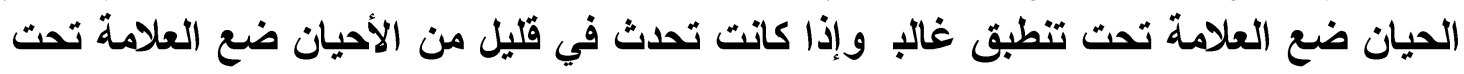

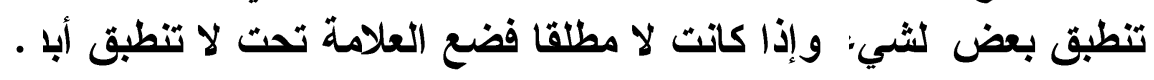

